\title{
Review Article \\ Hsp90 Inhibitors for the Treatment of Chronic Myeloid Leukemia
}

\author{
Kalubai Vari Khajapeer and Rajasekaran Baskaran \\ Department of Biochemistry and Molecular Biology, School of Life Sciences, Pondicherry University, Pondicherry 605014, India \\ Correspondence should be addressed to Rajasekaran Baskaran; baskaran.rajasekaran@gmail.com
}

Received 26 August 2015; Revised 11 November 2015; Accepted 12 November 2015

Academic Editor: Massimo Breccia

Copyright ( $) 2015$ K. V. Khajapeer and R. Baskaran. This is an open access article distributed under the Creative Commons Attribution License, which permits unrestricted use, distribution, and reproduction in any medium, provided the original work is properly cited.

\begin{abstract}
Chronic myeloid leukemia (CML) is a hematological malignancy that arises due to reciprocal translocation of $3^{\prime}$ sequences from c-Abelson (ABL) protooncogene of chromosome 9 with $5^{\prime}$ sequence of truncated break point cluster region (BCR) on chromosome 22. BCR-ABL is a functional oncoprotein p210 that exhibits constitutively activated tyrosine kinase causing genomic alteration of hematopoietic stem cells. BCR-ABL specific tyrosine kinase inhibitors (TKIs) successfully block CML progression. However, drug resistance owing to BCR-ABL mutations and overexpression is still an issue. Heat-shock proteins (Hsps) function as molecular chaperones facilitating proper folding of nascent polypeptides. Their increased expression under stressful conditions protects cells by stabilizing unfolded or misfolded peptides. Hsp90 is the major mammalian protein and is required by BCR-ABL for stabilization and maturation. Hsp90 inhibitors destabilize the binding of BCR-ABL protein thus leading to the formation of heteroprotein complex that is eventually degraded by the ubiquitin-proteasome pathway. Results of many novel Hsp90 inhibitors that have entered into various clinical trials are encouraging. The present review targets the current development in the CML treatment by availing Hsp90 specific inhibitors.
\end{abstract}

\section{Introduction}

Leukemia is a type of blood cancer in which unusual raise in number of white blood cells is found. Four types of leukemia are recognized by most cancer registries [1]. They are acute myeloid leukemia (AML), acute lymphoid leukemia (ALL), chronic myeloid leukemia (CML), and chronic lymphoid leukemia (CLL). CML is a hematoproliferative neoplasm that is marked by uncontrolled myeloid cell divisions in bone marrow [2]. CML is divided into three phases-chronic phase, accelerated phase, and blast crisis [3]. Although found in all age groups, CML more often occurs in middle aged and elderly people with a median age of 67 years [4]. CML accounts for $\sim 20 \%$ of all leukemia cases in adults in western population [5]. Estimated annual prevalence of CML is 1-2 per 1,00,000 population with greater frequency in males [6].

The mark of CML is the presence of shortened Philadelphia chromosome $(\mathrm{Ph})$ that occurs due to reciprocal translocation between chromosome 9 and chromosome $22[(9 ; 22)$ (q34;q11)], thereby eventually culminating in the genesis of the BCR-ABL oncogene. About $90 \%$ of CML patients have $\mathrm{Ph}$.
The BCR-ABL oncogene encodes a constitutively activated tyrosine kinase, BCR-ABL. Fusion at different break points in BCR gene locus produces 3 different oncoproteins, namely, p190, p210, and p230. p190 causes ALL [7]; p210 is the major protein involved in CML [2]. p230 is correlated with a mild form of CML.

\section{Signaling Pathways Affected by BCR-ABL}

BCR-ABL activates several pathways such as RAS, a small GTPase, mitogen activated protein kinase (MAPK), signal transducers and activator of transcription (STAT), and phosphoinositide 3-kinase (PI3K) pathways that regulate survival, proliferation, and apoptosis of leukemic cells [8-16] (Figure 1).

\section{Overview of Treatment for CML}

Since 1960, antimetabolites like cytarabine, busulfan (BUS), and hydroxyurea (HU) were used for the treatment of CML 


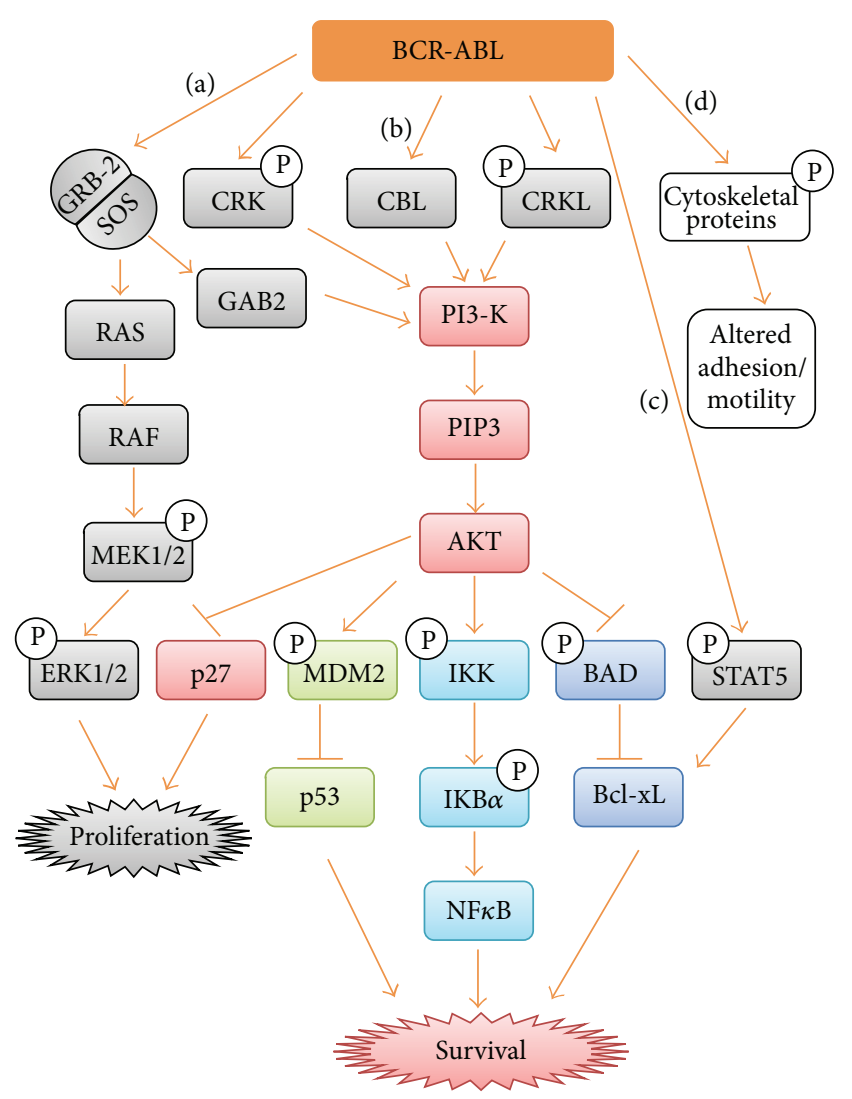

FIGURE 1: Signaling pathways activated by BCR-ABL. (a) BCRABL activates GRB-2/SOS which in turn activates RAS. Active RAS activates RAF. Active RAF stimulates MEK1, which in turn activates ERK1/2. Activation of Ras pathway by BCR-ABL aids CML cells proliferation. On the other hand, activated GRB-2/SOS stimulates GAB2 which activates PI3-K pathway. (b) BCR-ABL phosphorylates adaptor proteins like CRK and CRKL leading to the activation of PI3-K. PI3-K phosphorylates PIP2 to PIP3 which in turn activates AKT. AKT inhibits p27 leading to CML cells proliferation. AKT phosphorylates MDM2, which in turn inhibit p53. AKT activates $\mathrm{NF} \kappa \mathrm{B}$ via phosphorylation of IKK and $\operatorname{IkB} \alpha$. AKT inhibits pBAD. Activation of $\mathrm{NF} \kappa \mathrm{B}$ and inhibition of $\mathrm{p} 53$ and $\mathrm{BAD}$ by AKT evade apoptosis and promote CML cells survival. (c) BCR-ABL phosphorylates STAT5 which also aid in evading apoptosis of CML cells. (d) BCR-ABL phosphorylate cytoskeleton proteins resulting in increased cellular motility and reduced adhesion to extracellular matrix of bone marrow.

[8]. Later in 1970, allogeneic stem cell transplantation, in which patient receives stem cells from a genetically similar donor, was used as an effective therapy for CML. But this approach was risky due to limited availability of genetically identical persons and caused death in elderly people [17]. In 1980 , interferon- $\alpha($ IFN $-\alpha)$ proved effective for the treatment of CML. Such treatment prolonged the survival compared to BUS and HU [18]. Later, the discovery of tyrosine kinase inhibitors (TKIs) renewed the CML treatment (Figure 2) with increased survival rates, decreased side effects, and improved life quality (Table 1).

3.1. First-Generation TKI. Imatinib, a 2-phenylaminopyrimidine derivative (Figure 2), competes with the ATP binding site of c-ABL kinase of fusion BCR-ABL, found in CML cells [19]. Phase-I trials of imatinib showed significant antiproliferative activity in CML patients in which IFN- $\alpha$ treatment failed [20]. In addition to ABL, imatinib inhibits PDGFR, Arg, and c-Kit except Src kinases. Results of International Randomized Study of Interferon and STI571 (IRIS) trials showed reliability and supremacy of imatinib related to IFN$\alpha$ in terms of hematologic and cytogenetic responses [21]. Imatinib was legalized by the US, Food and Drug Administration (FDA) in 2001.

3.2. Resistance of Imatinib. Resistance of imatinib is of two types, BCR-ABL dependent and BCR-ABL independent. The former is due to mutations in the BCR-ABL kinase domain [22] and overexpression of BCR-ABL protein [23]. Point mutations in the BCR-ABL kinase domain decrease or inhibit the interaction of TKI with the aberrant BCR-ABL. The most prevalently observed mutation in CML patients resistant to imatinib is T315I. This mutation has isoleucine instead of threonine at the 315th amino acid in the BCR-ABL protein. Alterations in critical contact points due to amino acid substitutions increase the failure of TKI affinity to the target site. Amino acid substitutions at 7 residues result in mutations such as G250E, M244V, M351T, E255K/V, F359V, Y253F/H, and T315I. To date, over 90 point substitution mutations in BCR-ABL kinase domain have been distinguished in drug resistant CML patients. There are 4 regions that are essential for high frequency binding of imatinib (P-loop, SH-3, SH-2, and A-loop). The P-loop is responsible for phosphate binding and mutations in this site were frequently observed in $43 \%$ of patients who were generally in the acute and blast crisis phases. The P-loop mutations E255K and Y253F increase the probability of transformation depending on BCR-ABL kinase activity [24].

BCR-ABL independent resistance is due to LysM-containing receptor-like kinase (Lyn kinase) overexpression [25] and activation [26], increased levels of imatinib efflux transporters [e.g., ATP-binding cassette, sub-family B multidrug resistance (MDR)] [27], and the multidrug resistant protein 1 (MDA-1) [28].

3.3. Second Generation TKIs. To overcome intolerance and imatinib resistance in CML patients, development of secondgeneration TKIs such as dasatinib, bosutinib, and nilotinib was unfolded [29]. Various clinical studies like Dasatinib versus Imatinib Study in Treatment of Naive CML-Chronic Phase-Patients (DASISION) [30], Evaluating Nilotinib Efficacy and Safety in Clinical Trials-Newly Diagnosed Patients (ENESTnd) [31], and Bosutinib Efficacy and Safety in Newly Diagnosed CML (BELA) [32] trials showed efficacy and superiority of second-generation TKIs over first-generation TKI [33].

Dasatinib, a thiazolecarboxamide (Figure 2) binds to the BCR-ABL's ATP binding site with more compatibility than imatinib [34]. Dasatinib is capable of binding to both the open and closed conformations of BCR-ABL whereas imatinib binds only to the closed conformation of the BCR-ABL [35]. Dasatinib was affirmed by the US FDA in 2007 [36]. 
TABLE 1: Anti-CML TKIs.

\begin{tabular}{|c|c|c|c|c|c|c|}
\hline TKIs & Compound name & Previous name & Company & Trade name & Approval by US, FDA & Dosage \\
\hline $\begin{array}{l}\text { First- } \\
\text { generation } \\
\text { TKI }\end{array}$ & Imatinib & STI571, CPG57148B & Novartis & Gleevac or Glivec & 2001 & $\begin{array}{c}\text { CML-CP-400 mg } \\
\text { once daily }\end{array}$ \\
\hline \multirow{3}{*}{$\begin{array}{l}\text { Second- } \\
\text { generation } \\
\text { TKIs }\end{array}$} & Nilotinib & AMN107 & Novartis & Tasigna & 2006 & $\begin{array}{c}\text { CML- } \\
\text { CP/AP-400 mg } \\
\text { twice daily }\end{array}$ \\
\hline & Dasatinib & BMS354825 & $\begin{array}{c}\text { Bristol-Myers } \\
\text { Squibb }\end{array}$ & Sprycel & 2007 & $\begin{array}{l}\text { CML-CP-100 mg } \\
\text { once daily }\end{array}$ \\
\hline & Bosutinib & SKI606 & Pfizer & Bosulif & 2012 & $500 \mathrm{mg}$ once daily \\
\hline $\begin{array}{l}\text { Third- } \\
\text { generation } \\
\text { TKI }\end{array}$ & Ponatinib & AP24534 & Ariad & Iclusig & 2013 & $45 \mathrm{mg}$ once daily \\
\hline
\end{tabular}

${ }^{*} \mathrm{CP}$ : chronic phase; AP: accelerated phase.<smiles>Cc1ccc(NC(=O)c2ccc(CN3CCN(C)CC3)cc2)cc1Nc1nccc(-c2cccnc2)n1</smiles>

(a) Imatinib<smiles>Cc1cn(-c2cc(NC(=O)c3ccc(C)c(Nc4nccc(-c5cccnc5)n4)c3)cc(C(F)(F)F)c2)cn1</smiles>

(c) Nilotinib<smiles>Cc1nc(Nc2ncc(C(=O)Nc3c(C)cccc3Cl)s2)cc(N2CCN(CCO)CC2)n1</smiles>

(b) Dasatinib<smiles>COc1cc(Nc2c(C#N)cnc3cc(OCCCN4CCN(C)CC4)c(OC)cc23)c(Cl)cc1Cl</smiles>

(d) Bosutinib

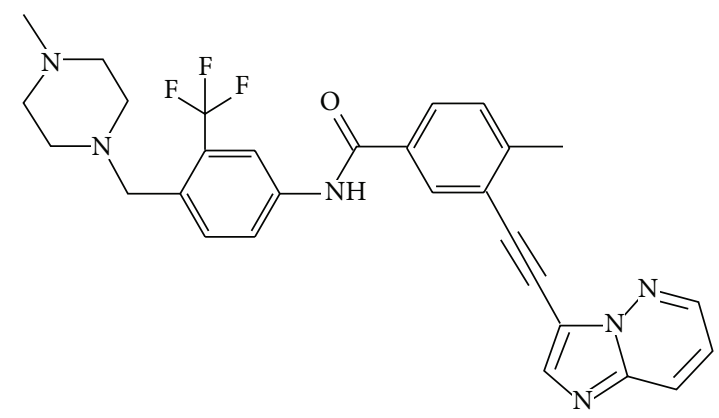

(e) Ponatinib

FIGURE 2: Currently available BCR-ABL specific TKIs for CML treatment. (a) First-generation TKI. ((b), (c), and (d)) Second-generation TKIs. (e) Third-generation TKI. 
Interestingly, dasatinib not only inhibits BCR-ABL and but also inhibits kinases like Src kinases (Src, Lck, and YES), cKit, PDGFR, and ephrin-A receptor [37].

Nilotinib, an aminopyrimidine (Figure 2) structurally related to imatinib, binds exclusively to the closed conformation of BCR-ABL. Nilotinib has more affinity in binding to the ATP-binding site of BCR-ABL than imatinib [38]. Nilotinib was approved in 2007 by US FDA as a subsequent treatment preference in CML patients in chronic phase, following imatinib. Nilotinib is similar to imatinib in inhibiting PDGFR, Arg, and Kit except Src kinases [39].

According to the instructions of the European Society for Medical Oncology and National Comprehensive Cancer Network Guidelines in Oncology (NCCN) we recommend imatinib, dasatinib, or nilotinib as first line therapy for lately found CML patients in chronic phase [5].

Bosutinib is a 4-anilino-3-quinoline carbonitrile (Figure 2) that inhibits both ABL and Src kinases [40]. Bosutinib is recommended for imatinib resistance CML patients as well as in recently diagnosed CML patients in chronic phase [41]. Importantly, low doses of bosutinib inhibit BCR-ABL when compared to imatinib. Bosutinib is effective against most Gleevac resistant mutations except T315I and V299L substitutions [42].

3.4. Third-Generation TKI. BCR-ABL-T315I is the leading mutation that accounts for resistance to cytotoxic drugs, firstand second-generation TKIs. To combat imatinib resistance in CML patients, third-generation TKIs were developed.

Ponatinib (AP24534) is a third-generation TKI (Figure 2) that inhibits both wild type and BCR-ABL harboring mutations such as M244V, G250E, Q252H, Y253F/H, E255K/V, F317L, M351T, and F359V. Ponatinib is developed to inhibit exclusively T315I mutation of BCR-ABL [43].

\section{In Vitro CML Cell Line Model}

Currently, more than $40 \mathrm{CML}$ derived cell lines have been documented. Of these, K562 is a BCR-ABL positive CML cell line that was established from 53-year-old woman with CML in blast crisis stage [44]. After 176 passages in 3.5 years, K562 cell line still has active CML cells in blast crisis stage with $\mathrm{Ph}$ [45]. In fact, CML induction in mice is carried out by injecting K562 cells into their tail vein. K562 is well reliable BCR-ABL positive CML model to test the efficacy of a desired drug [46].

\section{Heat Shock Proteins: An Overview}

Initially discovered in Drosophila by Ritossa in 1996 [47], heat shock proteins (Hsps) function as molecular chaperones facilitating proper folding and maturation of nascent polypeptides [48]. Hsps protect against protein aggregation in cytosol [49]. Hsps are highly conserved and universally expressed in all species from bacteria to plants and animals [50]. These are produced by cells under stressful conditions such as heat, hence the name heat shock proteins. Later, Hsps were found to be rapidly explicated in response to stress conditions such as hypoxia, ischemia, hyperoxia, anoxia, exposure to UV light, nutrient deficiencies (e.g., glucose deprivation), and heavy metals [51]. Heat shock transcriptional factors (HSFs) are protein family that supervises the transcription of Hsp genes [52]. In mammals, major HSFs include HSF1, HSF2, and HSF4. Of these, HSF1 is the main regulator of Hsps production [53].

Under normal physiological conditions, HSF1 remains as a monomer and is tightly bound to Hsp90 [54]. In response to stress, because of increased denatured and improperly folded proteins in the cell, HSF1 dissociates from the Hsp90-HSF1 complex. Released HSF1 from the cytosol translocates into the nucleus and binds to heat shock response element (HSRE) in DNA and induces the production of Hsps. Hsps prevent protein denaturation in cells facing stress conditions [55].

5.1. Classification of Hsps. Based on their molecular weight, Hsps have been classified into five major classes. They are small Hsps, Hsp60, Hsp70, Hsp90, and Hsp100. Out of these, Hsp90 is a major cytosolic protein that constitutes about 1$2 \%$ of total cytosolic protein [56]. It exhibits four isoforms which include Hsp90 $\alpha$, Hsp90 $\beta$, glucose-regulated protein94 (GRP-94), and TNF receptor associated protein-1 (TRAP1) [57]. Of these, Hsp90 $\alpha$ is the major isoform [58].

5.2. Hsp90 Structure. Hsp90 exists as a homodimer. It consists of three major regions-a $25 \mathrm{kDa} \mathrm{N}$-terminal domain, $40 \mathrm{kDa}$ middle domain, and $12 \mathrm{kDa}$ C-terminal domain [59]. In addition, a charged linker region between the $\mathrm{N}$-terminal and the middle domain is located. The N-terminal domain has an ATP binding site and shows homology to other ATPase/kinases like gyrase, histidine kinase, and mutL super family [60]. Various client proteins bind to the middle domain of Hsp90 [61]. C-Domain has an alternate ATP binding site. At the end of C-terminal, a tetratricopeptide repeat (TPR) motif, which has a preserved MEEVD pentapeptide intended for Hsp90 interaction with its co-chaperons, is present [62]. Hsp90 mediated protein folding is an ATP dependent process. Various cochaperons like cell division control protein 37 (cdc37), Hsp organizing protein (Hop), activator of Hsp90 ATPase (Aha1), and p23 and FK506binding protein 51/52 (FKBP51/52) aid Hsp90 in the appropriate folding of client proteins [63].

\section{Hsp90 and Cancer}

When compared to normal cells, cancer cells are under physiological stress like hypoxia, ischemia, and nutrient deficiencies (e.g., glucose deprivation). Hence, production of Hsps is ten times higher in tumor cells. Many proteins/factors associated with the six hallmarks of cancer (Figure 3 ) such as Akt, Src, Flt3, cdk4, cdk6, telomerase, MEK, Raf, HIF1, and BCR-ABL are client proteins of Hsp90 [64].

Moreover, it is now well documented that Hsp90 is requisite for stabilization and proper functioning of these multiple mutated, cancerous proteins that assist cancer cell growth, survival, and malignancy [65]. More than 200 client proteins including hormone receptors, structural proteins [66], tyrosine kinases, and transcription factors [67] require 


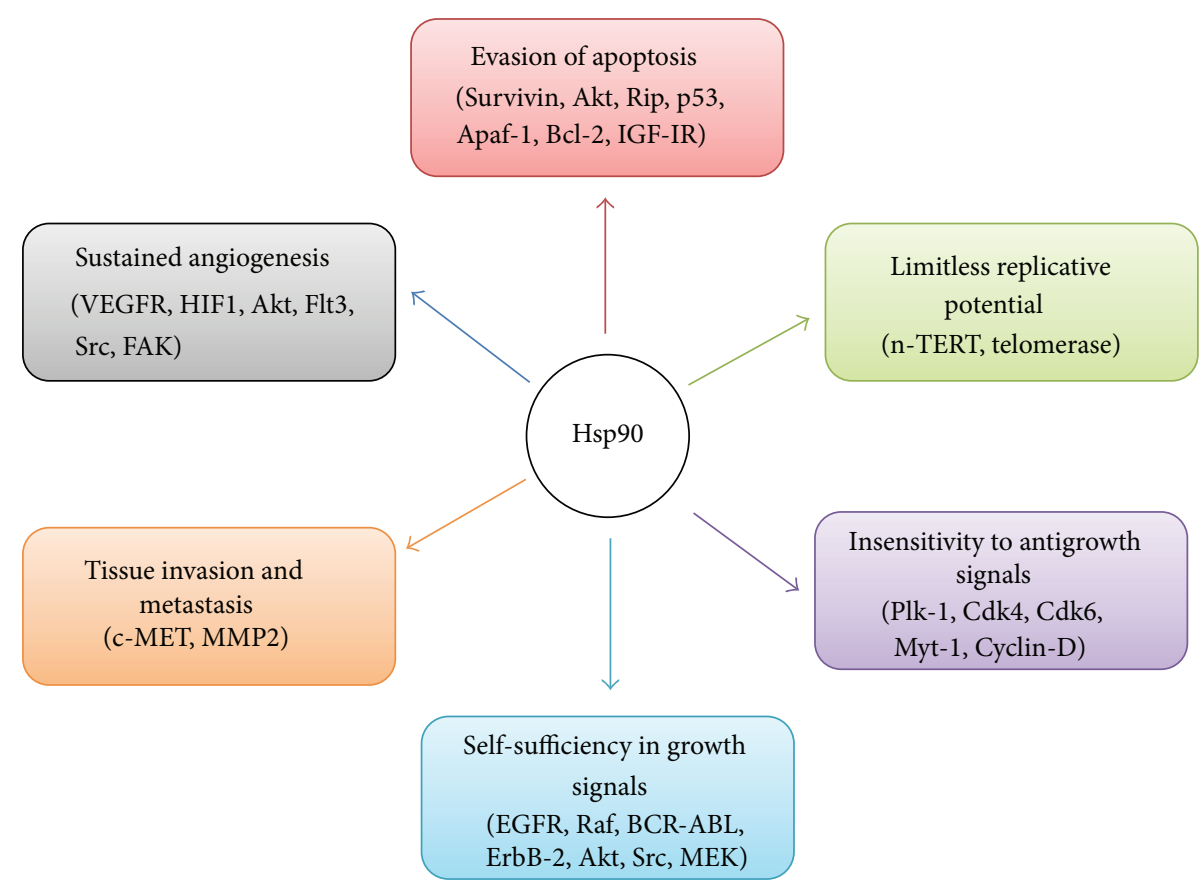

FIGURE 3: Relationship between Hsp90 and various client proteins resulting in cancer cell survival, progression, invasion, and metastasis.

Hsp90 for proper functioning and facilitating growth and survival [68]. Cancer cells exploit Hsp90 to back these activated oncoproteins that are foremost for oncogenic alteration. In this manner, Hsp90 assist cancer cells to survive in an inhospitable environment [69]. A specific role of Hsp90 in maintenance of tumor cell is to inhibit apoptosis [70].

\section{Hsp90 and CML}

In normal cells Hsp90 levels are low, whereas in CML cells Hsp90 levels are elevated. Hence, elevated Hsp90 levels could serve as prognostic marker in CML [71]. Increased Hsp90 protect fusion oncoprotein BCR-ABL by inhibiting its degradation (Figure 4(a)). In this way, Hsp90 prevent CML cells from apoptosis and promote cell survival and progression. Blocking the binding of BCR-ABL to Hsp90, through Hsp90 inhibitors, causes BCR-ABL degradation via ubiquitin proteasomal pathway (Figure 4(b)) (Table 2).

\subsection{Hsp90 Inhibitors from Microbial Origin}

7.1.1. Benzoquinone Ansamycin Derivatives. Geldanamycin (GDA) was isolated from Streptomyces hygroscopicus [72]. GDA is a benzoquinone ansamycin antibiotic that binds to the N-terminal domain of Hsp90 and inhibits its activity (Figure 5). GDA is poorly soluble in water and highly hepatotoxic due to the presence of methyl group at C-17. Analogues of GDA, 17-allylamino-17-demethoxygeldanamycin (17AAG) or tanespimycin and 17-dimethylaminoethylamino17-demethoxygeldanamycin (17DMAG) or alvespimycin (Figure 5) were consequently synthesized. 17AAG is more soluble and showed more potent activity than GDA [73]. Both GDA and 17AAG lowered BCR-ABL levels and lead CML cells to apoptosis. In addition to BCR-ABL, GDA lowered cellular levels of c-Raf and Akt [74]. 17DMAG showed higher potency, more bioavailability, and less toxicity compared to 17AAG and has entered into clinical trials [75]. 17DMAG along with PD184352, a mitogen protein kinase inhibitor, downregulated ERK1/2 and Bcl-xL levels and caused apoptosis in CML cells sensitive as well as resistant to imatinib [76]. The synergistic effect of LBH589, a histone deacetylase inhibitor, and 17AAG downregulated pFlt3, p-Akt, p-ERK1/2, and BCR-ABL levels in CML cells [77]. The combinational treatment of 17AAG and histone deacetylase inhibitor, suberoylanilide hydroxamic acid, caused mitochondrial damage, activated caspases 3 and 9, and induced apoptosis in CML cells. It also lowered Mcl-1, Raf-1, p27, p34, and p-ERK1/2 levels [78].

Ganetespib (STA-9090) is a non-geldanamycin resorcinol containing triazolone (Figure 5) that is presently in phase II clinical trials for the treatment of solid tumor and hematological malignancy [79]. Ganetespib inhibits Hsp90 activity by blocking the coupling of p23 cochaperone to Hsp90. Ganetespib ( $\mathrm{IC}_{50}$ is $\left.2-30 \mathrm{nM}\right)$ is more potent than $17 \mathrm{AAG}\left(\mathrm{IC}_{50}\right.$ is $20-$ $3500 \mathrm{nM}$ ) and caused cell death in non-small cell lung cancer (NSCLC) models [80]. Ganetespib showed potent activity against primary AML cells and also in combination with cytarabine caused significant cell death [81].

Herbimycin A is a 19-membered macrocyclic lactam (Figure 5) isolated from Streptomyces hygroscopicus [82]. Herbimycin A exhibits herbicidal, antifungal, antiangiogenic, and antitumor activities. Herbimycin A modulates Hsp90 thus interrupting it from coupling to its client proteins [83]. 

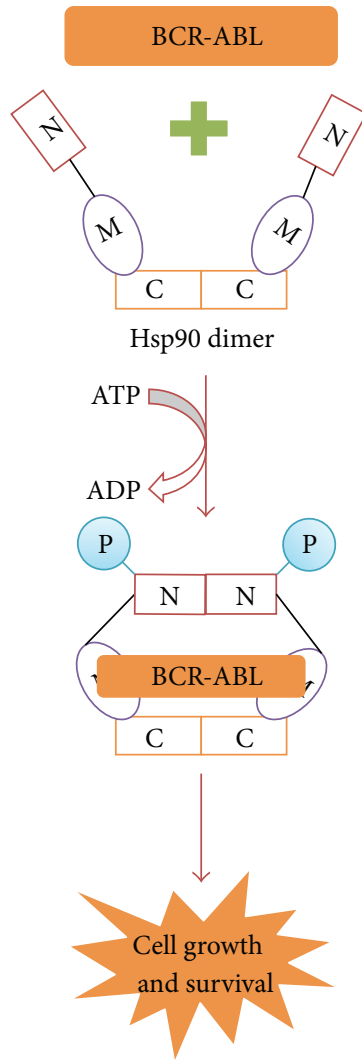

(a)

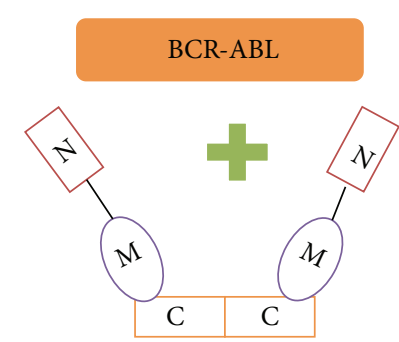

Hsp90 dimer

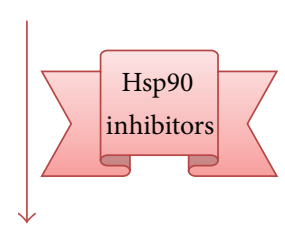

BCR-ABL

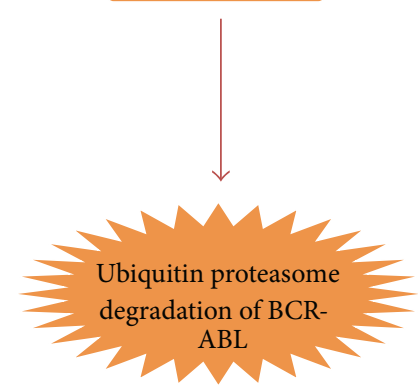

(b)

FIGURE 4: BCR-ABL functioning in the presence and absence of Hsp90 inhibitors. (a) In CML cells, Hsp90 levels are elevated. Hence oncoprotein BCR-ABL binds to Hsp90 for stabilization and maturation. Hence, stabilized BCR-ABL then activates many signaling pathways leading to CML cells survival, progression, and malignancy. (b) Blocking Hsp90 chaperone activity by employing Hsp90 inhibitors results in BCR-ABL degradation via ubiquitin proteasome pathway.

The synergistic effect of herbimycin A and TKI made CML cells more susceptible to apoptosis [84].

Macbecin I and Macbecin II (Figure 5) isolated from Nocardia species belong to benzoquinone ansamycin group [85]. Macbecin sticks to the ATP binding site of $\mathrm{N}$-terminal of Hsp90. Macbecin is more stable and soluble than GDA. Macbecin I exhibited cytotoxic and antitumor activities against leukemia P388, melanoma B16, and Ehrlich carcinoma in mice [86].

7.1.2. Radicicol. Radicicol is a 14-membered macrolide (Figure 5) isolated from Diheterospora chlamydosporia and Monosporium bonorden. Like GDA, radicicol binds to the ATP binding site located at the N-terminus of Hsp90 [87]. Radicicol lacks in vivo anticancer activity as it is converted to inactive metabolites in vivo. To overcome this, oxime derivatives of radicicol such as KF25706, KF29518, and KF58333 (Figure 5) were synthesized [88]. Among these, KF25706 destabilizes interaction between Hsp90 and its associated molecules [89]. Radicicol decreased phosphorylated Raf- 1 and BCR-ABL protein levels in CML cells. Radicicol also caused BCR-ABL inactivation via Hsp90 inhibition in K562 cells [90].
7.1.3. Coumermycin Family. Novobiocin (NB), Coumermycin A1 (Figure 5), and Clorobiocin belong to the coumermycin antibiotic family. They were isolated from Streptomyces spheroids. NB binds avidly to the C-terminal of Hsp90 and inhibits its activity [91]. NB reduced p-Akt, p-ERK, and pBCR-ABL levels in CML cells. NB also decreased the coupling of BCR-ABL to Hsp90 and caused BCR-ABL degradation via proteasome-ubiquitin pathway in K562 cells. Moreover NB not only inhibited proliferations but also lowered levels of BCR-ABL in K562 cells resistant to imatinib [92].

\subsection{Hsp90 Inhibitors from Plant Origin}

7.2.1. Epigallocatechin-3-gallate (EGCG). EGCG is a polyphenol compound (Figure 6) isolated from green tea Camellia sinensis [93]. EGCG is a C-terminus inhibitor and suppresses Hsp90 activity [94, 95]. In combination with ponatinib, EGCG induced significant apoptosis in CML cells. CyclinD1 and CDC25A levels were downregulated by this treatment in CML cells [96].

7.2.2. Taxol. Taxol (Figure 6), isolated from Taxus baccata L. [97], agent stabilizes microtubule formation and induces 
TABLE 2: BCR-ABL signaling pathways affected by Hsp90 inhibitors.

\begin{tabular}{|c|c|c|c|c|c|c|}
\hline S. number & $\begin{array}{l}\text { Name of the } \\
\text { compound }\end{array}$ & Isolated from & $\begin{array}{l}\text { Nature of } \\
\text { origin }\end{array}$ & $\begin{array}{c}\text { Mechanism of inhibition of } \\
\text { Hsp90 }\end{array}$ & $\begin{array}{l}\text { Signaling protein } \\
\text { downregulated by } \\
\text { Hsp90 inhibitors }\end{array}$ & References \\
\hline 1 & Geldanamycin & $\begin{array}{l}\text { Streptomyces } \\
\text { hygroscopicus }\end{array}$ & Bacterial & $\begin{array}{l}\text { Binds to N-terminal } \\
\text { domain of Hsp90 }\end{array}$ & $\begin{array}{c}\downarrow \mathrm{c}-\mathrm{Raf}, \\
\downarrow \mathrm{Akt}, \\
\downarrow \mathrm{BCR}- \\
\mathrm{ABL}\end{array}$ & {$[74]$} \\
\hline 2 & Radicicol & $\begin{array}{c}\text { Diheterospora } \\
\text { chlamydosporia and } \\
\text { Monosporium bonorden }\end{array}$ & Fungal & $\begin{array}{l}\text { Binds to N-terminal } \\
\text { domain of Hsp90 }\end{array}$ & $\begin{array}{l}\downarrow \mathrm{p}-\mathrm{Rafl} 1 \\
\downarrow \mathrm{p}-\mathrm{BCR}- \\
\mathrm{ABL}\end{array}$ & {$[90]$} \\
\hline 3 & Novobiocin & Streptomyces spheroids & Bacterial & $\begin{array}{l}\text { Binds to C-terminal } \\
\text { domain of Hsp90 }\end{array}$ & $\begin{array}{c}\downarrow \mathrm{p}-\mathrm{Akt} \\
\downarrow \mathrm{p}-\mathrm{ERK} \& \\
\downarrow \mathrm{p}-\mathrm{BCR}- \\
\mathrm{ABL}\end{array}$ & {$[91,92]$} \\
\hline 4 & $\begin{array}{l}\text { Epigallocatechin-3- } \\
\text { gallate }\end{array}$ & Camellia sinensis & Plant & $\begin{array}{l}\text { Binds to C-terminal } \\
\text { domain of Hsp90 }\end{array}$ & $\begin{array}{l}\downarrow \text { CyclinD1, } \\
\downarrow \text { CDC25A }\end{array}$ & {$[96]$} \\
\hline 5 & Taxol & Taxus baccata L. & Plant & NYK & $\begin{array}{l}\downarrow \text { pSTAT3, } \\
\downarrow \text { pSTAT5, } \\
\downarrow \text { p-CRKL } \\
\downarrow \text { p-Lyn }\end{array}$ & {$[101]$} \\
\hline 6 & Gambogic acid & Garcinia hanburyi & Plant & $\begin{array}{l}\text { Binds to N-terminal } \\
\text { domain of Hsp90 }\end{array}$ & $\begin{array}{c}\downarrow \downarrow \text { p-BCR- } \\
\text { ABL } \\
\downarrow \text { pSTAT5 } \\
\downarrow \text { p-CRKL } \\
\downarrow \text { pERK1/2, } \\
\downarrow \text { p-Akt \& } \\
\downarrow \text { p-BCR- } \\
\text { ABL } \\
\end{array}$ & {$[103,104]$} \\
\hline 7 & Celastrol & $\begin{array}{c}\text { Tripterygium wilfordii } \\
\text { Hook F }\end{array}$ & Plant & $\begin{array}{l}\text { Disrupts binding of Cdc37 } \\
\text { to Hsp90 }\end{array}$ & $\begin{array}{c}\text { pSTAT5, } \\
\downarrow \text { p-CRKL, } \\
\downarrow \text { pERK1/2, } \\
\downarrow \text { p-Akt, } \\
\downarrow \text { p-BCR- } \\
\text { ABL, } \\
\downarrow \text { Bcl-xL, } \\
\downarrow \text { Mcl-1, } \\
\downarrow \text { survivin }\end{array}$ & {$[107,108]$} \\
\hline 8 & Curcumin & $\begin{array}{l}\text { Curcuma aromatica, } \\
\text { Curcuma longa, and } \\
\text { Curcuma phaeocaulis }\end{array}$ & Plant & NYK & $\begin{array}{l}\downarrow \text { BCR- } \\
\text { ABL, } \\
\downarrow \text { CRKL, } \\
\downarrow \text { STAT5 }\end{array}$ & {$[110,111]$} \\
\hline 9 & Withaferin A & Withania somnifera & Plant & $\begin{array}{l}\text { Disrupts the binding of } \\
\text { Cdc37 to Hsp90 }\end{array}$ & $\begin{array}{l}\downarrow \mathrm{NF} \kappa \mathrm{B}, \\
\downarrow \mathrm{Bcl}-2, \\
\downarrow \mathrm{Bim}, \\
\downarrow \mathrm{p}-\mathrm{Bad}\end{array}$ & {$[114,115]$} \\
\hline 10 & $\begin{array}{l}\text { 5-Episinuleptolide } \\
\text { acetate }\end{array}$ & Sinularia species & Coral & NYK & $\begin{array}{c}\downarrow \mathrm{c}-\mathrm{ABL}, \\
\downarrow \mathrm{Akt}, \\
\downarrow \mathrm{NF} \kappa \mathrm{B}\end{array}$ & {$[116]$} \\
\hline
\end{tabular}

${ }^{*}$ NYK: not yet known.

apoptosis via mitotic catastrophe [98]. Taxol inhibits Hsp90 activity $[99,100]$. Synergistic effect of paclitaxel and bortezomib, a proteasome inhibitor, reduced the autophosphorylated levels of BCR-ABL. Moreover, this combinational treatment attenuated BCR-ABL downstream signaling pathways, decreasing phosphorylated STAT3, STAT5, CRKL, and Lyn levels. It also activates caspases 3, 8, and 9 causing apoptosis of CML cells via poly(ADP-Ribose) polymerase (PARP) cleavage [101].

7.2.3. Gambogic Acid (GA). GA is a main component of (Figure 6) Chinese plant, Garcinia hanburyi (gamboge) [102]. GA binds to N-terminus of Hsp90 and inhibits its activity. GA was approved by China FDA and entered into phase-II 
<smiles>COC1=C(C[C@@H](C)C[C@H](OC)[C@@H](O)[C@@H](C)/C=C(\C)[C@H](OC(N)=O)[C@@H](O)/C=C\C=C(/C)C(=O)NC2=CC(=O)C(OC)=C(C)C2=O)C(=O)O1</smiles>

(a) Geldanamycin<smiles>[2H]O[C@H]([C@@H](C)/C=C(\C)[C@@H](OC(N)=O)[C@@H](C)/C=C\C=C(/C)C(=O)NC1=CC(=O)C(NCC=C)=C(C)C1=O)[C@@H](C[C@H](C)CC1=C(NCC=C)OC1=O)OC</smiles>

(b) 17-AAG

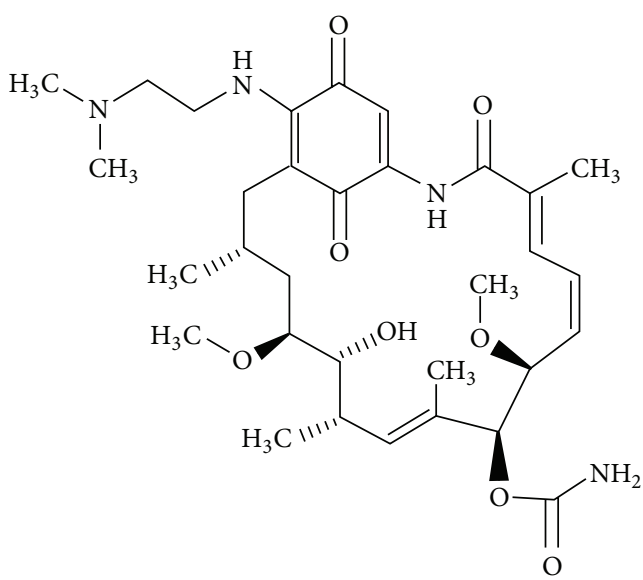

(c) 17-DMAG<smiles>CC(C)c1cc(-c2n[nH]c(=O)n2-c2ccc3c(ccn3C)c2)c(O)cc1O</smiles>

(d) Ganetespib<smiles>CO[C@@H](C)C[C@@H](C)[C@H](C)/C=C(\C)[C@H](OC)[C@H](/C=C\C=C(\C)C(=O)NC1=CC(=O)C=C([C@@H](OC)[C@@H](C)OC)C1=O)OC</smiles>

(e) Herbimycin $\mathrm{A}$

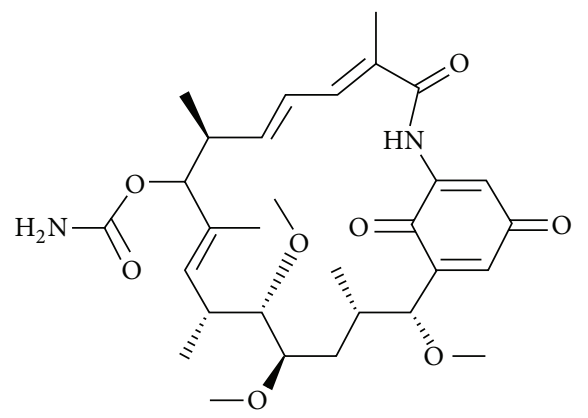

(f) Macbecin<smiles>C[C@@H]1C[C@H]2O[C@H]2/C=C\C=C\C(=O)Cc2c(Cl)c(O)cc(O)c2C(=O)O1</smiles>

(g) Radicicol<smiles>C[C@@H]1C[C@@H]2O[C@H]2/C=C\C=C\C(=N/O)Cc2c(Cl)c(O)cc(O)c2C(=O)O1</smiles>

(h) KF25706<smiles>COC1C(OC(N)=O)C(O)C(Oc2ccc3c(O[N+]([O-])O)c(NC(=O)c4ccc(O)c(CC=C(C)C)c4)c(=O)oc3c2C)C(C)(C)C1O</smiles>

(i) Novobiocin

FIGURE 5: Hsp90 inhibitors of microbial origin. 
<smiles>O=C(O[C@H]1Cc2c(O)cc(O)cc2O[C@@H]1c1cc(O)c(O)c(O)c1)c1cc(O)c(O)c(O)c1</smiles>

(a) EGCG<smiles>CC(=O)OC1C(=O)C2(C)C(O)CC3OC[C@@]3(OC(C)=O)[C@@]2(C)C(OC(=O)c2ccccc2)[C@H](O)C1(C)C</smiles>

(b) Taxol<smiles>CC(C)=CCC[C@]1(C)C=Cc2c(O)c3c(c(CC=C(C)C)c2O1)OC12C(=CCC(=O)[C@@]1(CC=C(C)C(=O)O)OC2(C)C)C3=O</smiles>

(c) Gambogic acid<smiles>CC1=C(O)C(=O)C=C2CC[C@H]3C(=CC=C21)[C@@]1(C)CC[C@@H]2[C@](C)(CC[C@@]2(C)C(=O)O)C[C@@H]31</smiles>

(d) Celastrol<smiles></smiles>

(f) Withaferin A<smiles>COc1cc(/C=C/C(=O)CC(=O)/C=C/c2ccc(O)c(OC)c2)ccc1O</smiles>

(e) Curcumin

FIGURE 6: Hsp90 inhibitors of plant origin.

clinical trials. GA deregulates the expression of Src-3, Akt, and VEGFR2, resulting in the apoptosis of tumor cells [103]. GA not only induced apoptosis but also reduced cell proliferation in CML cells. GA lowered BCR-ABL levels in wild and resistant CML cells in vivo. GA decreased the levels of p-STAT5, p-CRKL, p-ERK1/2, and p-Akt [104].

7.2.4. Celastrol. Celastrol is a quinone methide triterpene (Figure 6) isolated from the poisonous plant Tripterygium wilfordii Hook F (Thunder God Vine). Celastrol is used in the medication against inflammation, asthma, and allergic conditions [105]. Celastrol disrupts the binding of Cdc37 to
Hsp90, thus inhibiting its activity [106]. Importantly, celastrol triggers the degradation of BCR-ABL and Flt3 [107]. Both in vitro and in vivo studies showed that celastrol decreased phosphorylated BCR-ABL, Akt, Erk1/2, and STAT5 protein levels. Celastrol also lowered antiapoptotic (Bcl-xL, Mcl-1, and survivin) protein levels and induced apoptosis in $\mathrm{CML}$ cells harboring T135I mutation [108].

7.2.5. Curcumin. Curcumin, isolated from Curcuma plant species (Figure 6) like Curcuma aromatica, Curcuma longa, and Curcuma phaeocaulis, exhibits antioxidant, anti-inflammatory, and antitumor activities. Several lines of studies 


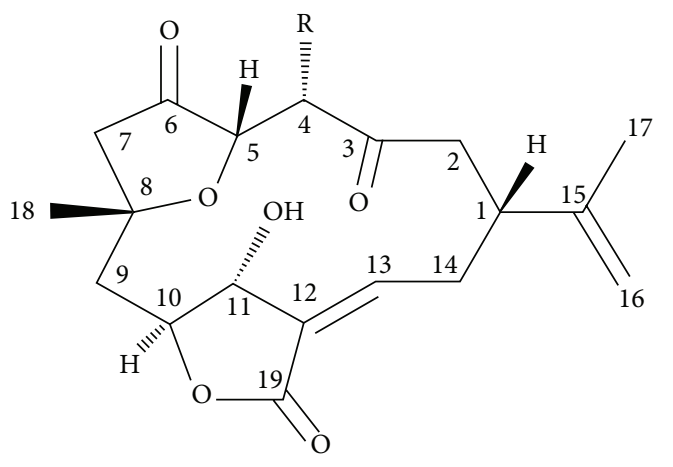

1: $\mathrm{R}=\mathrm{H}, 2: \mathrm{R}=\mathrm{OH}$

5-Episinuleptolide acetate

FIGURE 7: Hsp90 inhibitors of coral origin.

demonstrated the antileukemic activity on ALL cells both in vitro and in vivo. Curcumin inhibits ABL, STAT, Akt, and mTOR signaling pathways causing apoptosis of CML cells [109]. Curcumin inhibits Hsp90 activity [110]. C817, a novel derivative of curcumin, inhibits both wild and mutant ABL kinase activities (Q252H, Y253F, and T315I). In addition, C817 downregulates phosphorylated BCR-ABL, CRKL, and STAT5 protein levels [111].

7.2.6. Withaferin A. Withaferin A is a steroidal lactone (Figure 6) isolated from the Indian medicinal plant, Ashwagandha (Withania somnifera) [112]. Withaferin A interferes with Hsp90-Cdc37 chaperone complex by regulating leucine rich repeat kinase 2 (LRRK2) levels [113]. Withaferin A reduced the levels of $\mathrm{NF} \kappa \mathrm{B}$ and potently inhibited the growth of human and murine B cell lymphoma cell lines [114]. Withaferin A induced caspase activation and caused apoptosis in doxorubicin-sensitive K562 and doxorubicinresistant K562/Adr cells. Moreover, it downregulated Bcl-2, Bim, p-Bad, and cytoskeletal tubulin protein levels. Hence, Withaferin A overcomes the MDR caused by the overexpression of P-glycoprotein (P-gp) in K562 levels with attenuated apoptosis [115].

\subsection{Hsp90 Inhibitors from Coral Origin}

7.3.1. 5-Episinuleptolide Acetate (5EPA). 5EPA is a macrocyclic $3(2 \mathrm{H})$-furanone-based norcembranoidal diterpene (Figure 7) isolated from the formosan soft coral Sinularia species. 5EPA exhibits antiproliferative activity against K562, HL60, and Molt4 cancer cell lines. 5EPA also lowered c-ABL, Akt, and NF $\kappa$ B levels in CML cells. 5EPA induced apoptosis in leukemic cells via Hsp90 inhibition [116].

\section{Evaluation of Hsp90 Function or Hsp90 Inhibition}

Hsp90 function or inhibition could be evaluated by the following assays. They are as follows.
8.1. Coupled Enzyme Assay. Hsp90 requires ATP for its molecular chaperone activity [63]. The ADP generated by Hsp90 is coupled with phosphoenol pyruvate to generate ATP and pyruvate catalyzed by pyruvate kinase enzyme. Then, pyruvate is converted into lactate by lactate dehydogenase enzyme with the expenditure of NADH. This assay is done to assess the ATPase activity of Hsp90. In this assay for every ADP generated by Hsp90, one NADH is consumed (Figure 8(a)). Low NADH levels lead to the decrease in UV absorbance at $340 \mathrm{~nm}$ [117].

8.2. Malachite-Green Assay. This assay is also designed to evaluate the ATPase activity of Hsp90 [63]. The cationic dye malachite-green along with the phosphomolybdate reacts with inorganic phosphate released to give a blue color having absorption maxima at $610 \mathrm{~nm}[118,119]$.

8.3. Hsp90 Inhibition Using Western Blotting. Hsp90 inhibition leads to the depletion of Hsp90 levels and its associated molecules in cells. The decreased Hsp90 levels could be observed by employing western blotting and densitometry studies [117].

8.4. Luciferase Refolding Assay. Luciferase is a bioluminescent photoprotein enzyme derived from firefly Photinus pyralis. Luciferase catalyzes the reaction of luciferin with ATP forming luciferyl adenylate, which in turn reacts with oxygen giving oxyluciferin. This reaction emits light [120]. In this assay the capability of a drug to inhibit Hsp90 is evaluated (Figure 8(b)). Denatured luciferase along with rabbit reticulocyte lysate (rich source of Hsp90 and its cochaperons) is incubated. The desired drug molecule is also incubated along with the above two. If the drug molecule is effective, it will inhibit the refolding of luciferase by Hsp90 [121].

\section{Hsp90 Inhibitors in Clinical Trials}

Of the several Hsp90 inhibitors identified, 17-AAG (NCT00100997) is currently under phase I clinical trial sponsored by Jonsson Comprehensive Cancer Center collaborated with National Cancer Institute (NCI) [122]. Efforts are undergoing to determine the side effects and best dose of 17-AAG in treating patients with CML in chronic phase that did not respond to imatinib mesylate. Ganetespib (NCT00964873) is in phase I clinical study to assess the safety and efficacy of once-weekly administered STA-9090 in patients with AML, ALL, and blast-phase CML. This study is sponsored by Synta Pharmaceuticals Corporation [123]. Paclitaxel (NCT00003230) is under Phase I/II trials to study the effectiveness in treating patients with refractory or recurrent acute leukemia or CML. This work is sponsored by Swiss Group for Clinical Cancer Research [124].

\section{Conclusions}

CML is a haematological malignancy that arises due to chromosomal translocation resulting in the presence of $\mathrm{Ph}$ chromosome. Initially, TKIs were designed to compete with the ATP binding site of BCR-ABL. TKIs effectively inhibited wild 


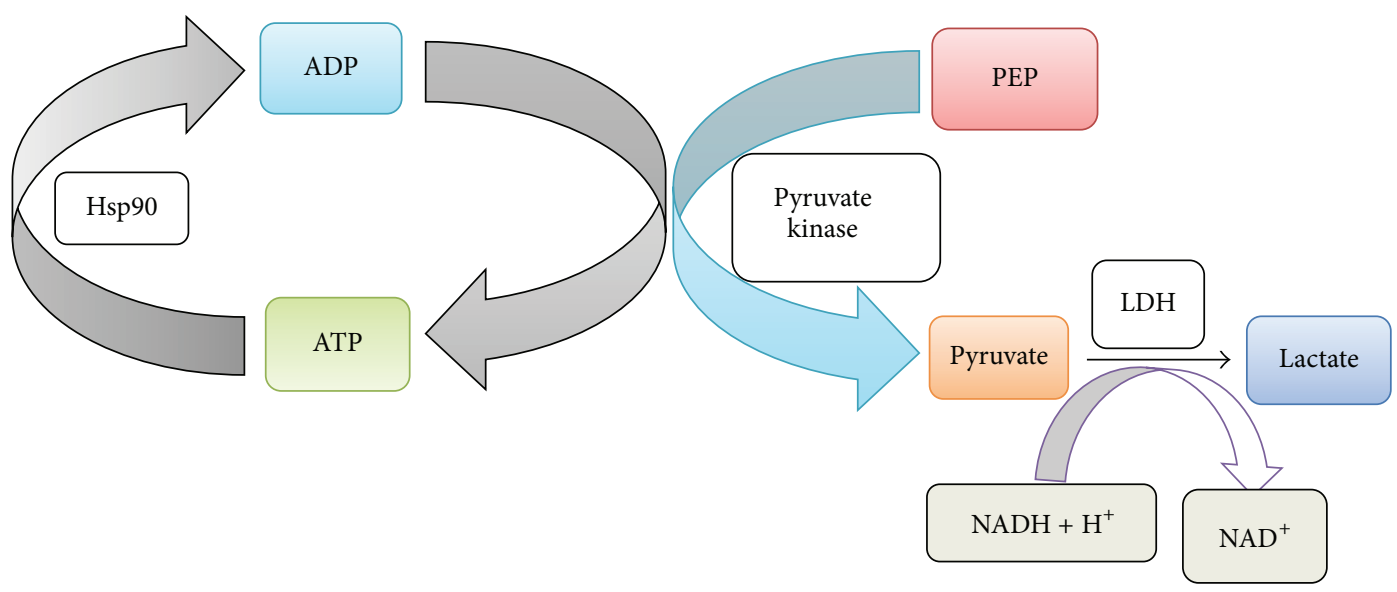

(a)

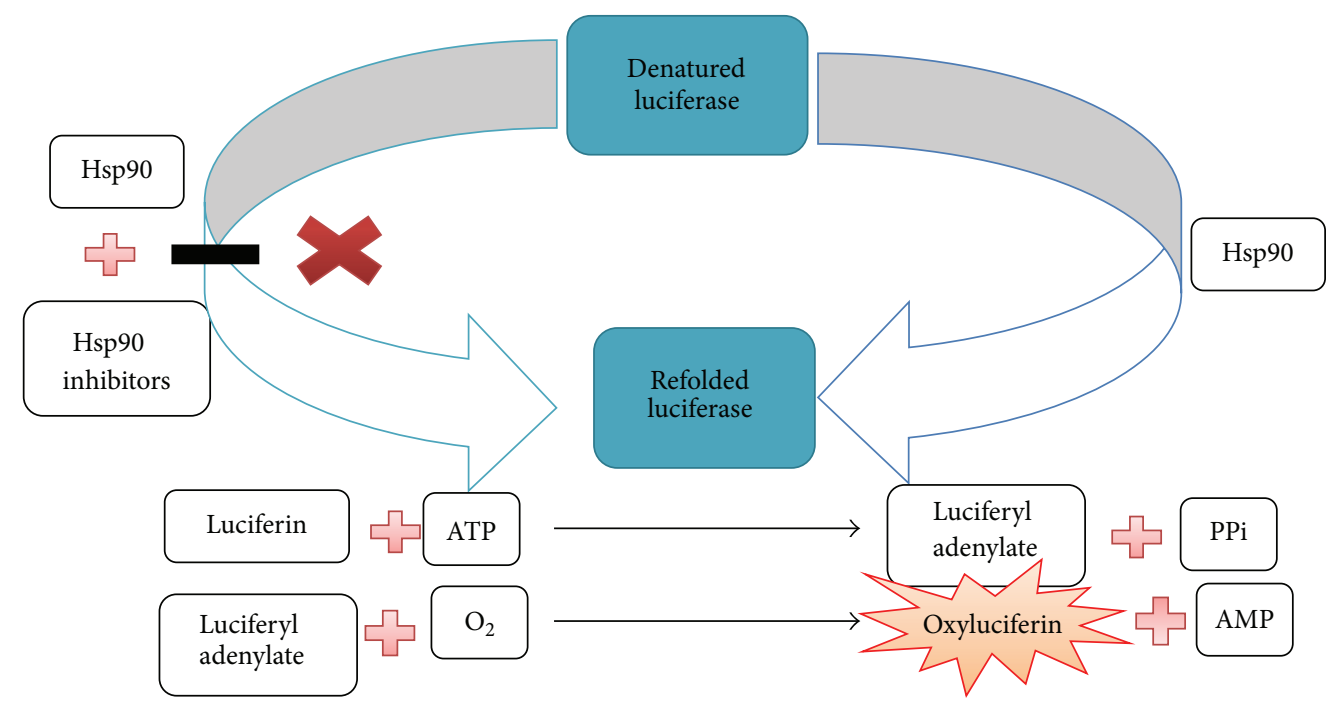

(b)

FiguRE 8: (a) Coupled enzyme assay. (b) Luciferase refolding assay.

BCR-ABL; however mutations in BCR-ABL and overexpression following treatment decreased their potency. Specifically, T315I mutation displayed resistance to both first- and secondgeneration TKIs. Eventually, ponatinib was developed to inhibit mutant T315I and was approved by the US FDA but was withdrawn due to toxicity.

Presently, there is a need for alternative strategy to develop new BCR-ABL inhibitors. Hsp90 is upregulated in CML cells for rapid proliferation, survival, and progression towards malignancy. Several Hsp90 inhibitors have been shown to inhibit and degrade BCR-ABL. In vitro studies unveiled that Hsp90 inhibitors alone or in combination with other inhibitors downregulate BCR-ABL levels in wild-type and TKI-resistant CML cells. Thus, suppressing the BCR-ABL protein levels through Hsp90 inhibition renders an attractive alternate strategy to combat CML.

\section{Abbreviations}

CLL: Chronic lymphoid leukemia

ALL: Acute lymphoid leukemia
CML: $\quad$ Chronic myeloid leukemia

AML: $\quad$ Acute myeloid leukemia

Ph: Philadelphia chromosome

ABL: c-Abelson

BCR: Break point cluster region

MAPK: Mitogen-activated protein kinase

STAT: $\quad$ Signal transducers and activator of transcription

PI3K: $\quad$ Phosphoinositide 3-kinases

BUS: Busulfan

HU: Hydroxyurea

IFN- $\alpha$ : Interferon- $\alpha$

TKI: $\quad$ Tyrosine kinase inhibitors

IRIS: $\quad$ International Randomized Study of Interferon and STI571

FDA: $\quad$ Food and Drug Administration

Lyn kinase: LysM-containing receptor-like kinase

MDR: Multidrug resistance

MDA-1: $\quad$ Multidrug resistant protein 1

DASISION: Dasatinib versus Imatinib Study In Treatment of Naive CML-CP patients 
ENESTnd: Evaluating Nilotinib Efficacy and Safety in Clinical Trials-Newly Diagnosed Patients

BELA: Bosutinib Efficacy and Safety in Newly Diagnosed CML

NCCN: National Comprehensive Cancer Network Guidelines in Oncology

Hsps: $\quad$ Heat shock proteins

HSFs: Heat shock transcriptional factors

HSRE: Heat shock Response Element

TPR: Tetratricopeptide repeat

GRP-94: Glucose-regulated protein-94

TRAP-1: $\quad$ TNF receptor associated protein-1

cdc37: $\quad$ Cell division control protein 37

Hop: $\quad$ Hsp organizing protein

Ahal: $\quad$ Activator of Hsp90 ATPase

FKBP51/52: FK506-binding protein 51/52

GDA: Geldanamycin

17AAG: 17-Allylamino-17-demethoxygeldanamycin

17DMAG: 17-Dimethylaminoethylamino-17-

demethoxygeldanamycin

NSCLC: Non-small cell lung cancer

NB: $\quad$ Novobiocin

EGCG: Epigallocatechin-3-gallate

PARP: Poly(ADP-Ribose) polymerase

GA: Gambogic acid

LRRK2: Leucine rich repeat kinase 2

5EPA: 5-Episinuleptolide acetate

P-gp: P-Glycoprotein

NCI: $\quad$ National Cancer Institute.

\section{Conflict of Interests}

The authors declare that they do not have any competing interests.

\section{Authors' Contributions}

All authors have equally contributed to drafting the paper. All authors read and approved the final paper.

\section{References}

[1] J. W. Vardiman, J. Thiele, D. A. Arber et al., “The 2008 revision of the World Health Organization (WHO) classification of myeloid neoplasms and acute leukemia: rationale and important changes," Blood, vol. 114, no. 5, pp. 937-951, 2009.

[2] S. Shahrabi, S. Azizidoost, M. Shahjahani, F. Rahim, A. Ahmadzadeh, and N. Saki, "New insights in cellular and molecular aspects of BM niche in chronic myelogenous leukemia," Tumor Biology, vol. 35, no. 11, pp. 10627-10633, 2014.

[3] A. Tefferi, "Classification, diagnosis and management of myeloproliferative disorders in the JAK2V617F era," Hematology, pp. 240-245, 2006.

[4] J. Chi, C. Pierides, A. Mitsidou, A. Miltiadou, P. Gerasimou, and P. Costeas, "cDNA synthesis for BCR-ABL1 detection at the MMR level: the importance of using the appropriate kit," Biological Procedures Online, vol. 17, article 4, 2015.

[5] E. J. Jabbour, J. E. Cortes, and H. M. Kantarjian, “Tyrosine kinase inhibition: a therapeutic target for the management of chronic-phase chronic myeloid leukemia," Expert Review of Anticancer Therapy, vol. 13, no. 12, pp. 1433-1452, 2013.

[6] X. An, A. K. Tiwari, Y. Sun, P.-R. Ding, C. R. Ashby, and Z.-S. Chen, "BCR-ABL tyrosine kinase inhibitors in the treatment of Philadelphia chromosome positive chronic myeloid leukemia: a review," Leukemia Research, vol. 34, no. 10, pp. 1255-1268, 2010.

[7] M. W. N. Deininger, J. M. Goldman, and J. V. Melo, "The molecular biology of chronic myeloid leukemia," Blood, vol. 96, no. 10, pp. 3343-3356, 2000.

[8] M. Sattler and J. D. Griffin, "Molecular mechanisms of transformation by the BCR-ABL oncogene," Seminars in Hematology, vol. 40, supplement 2, pp. 4-10, 2003.

[9] D. W. Sternberg and D. G. Gilliland, "The role of signal transducer and activator of transcription factors in leukemogenesis," Journal of Clinical Oncology, vol. 22, no. 2, pp. 361-371, 2004.

[10] F. Gesbert and J. D. Griffin, "Bcr/Abl activates transcription of the Bcl-X gene through STAT5," Blood, vol. 96, no. 6, pp. 22692276, 2000.

[11] D. A. Fruman, R. E. Meyers, and L. C. Cantley, "Phosphoinositide kinases," Annual Review of Biochemistry, vol. 67, pp. 481507, 1998.

[12] M. Karin, Y. Cao, F. R. Greten, and Z.-W. Li, "NF- $\kappa$ B in cancer: from innocent bystander to major culprit," Nature Reviews Cancer, vol. 2, no. 4, pp. 301-310, 2002.

[13] S. L. Campbell, R. Khosravi-Far, K. L. Rossman, G. J. Clark, and C. J. Der, "Increasing complexity of Ras signaling," Oncogene, vol. 17, no. 11, pp. 1395-1413, 1998.

[14] J. A. McCubrey, L. S. Steelman, W. H. Chappell et al., "Roles of the Raf/MEK/ERK pathway in cell growth, malignant transformation and drug resistance," Biochimica et Biophysica Acta, vol. 1773, no. 8, pp. 1263-1284, 2007.

[15] P. J. Roberts and C. J. Der, “Targeting the Raf-MEK-ERK mitogen-activated protein kinase cascade for the treatment of cancer," Oncogene, vol. 26, no. 22, pp. 3291-3310, 2007.

[16] J. Downward, "Targeting RAS signalling pathways in cancer therapy," Nature Reviews Cancer, vol. 3, no. 1, pp. 11-22, 2003.

[17] J. M. Goldman and J. V. Melo, "Chronic myeloid leukemiaadvances in biology and new approaches to treatment," The New England Journal of Medicine, vol. 349, no. 15, pp. 1451-1464, 2003.

[18] M. Talpaz, R. Hehlmann, A. Quintás-Cardama, J. Mercer, and J. Cortes, "Re-emergence of interferon- $\alpha$ in the treatment of chronic myeloid leukemia," Leukemia, vol. 27, no. 4, pp. 803812, 2013.

[19] T. Sacha, "Imatinib in chronic myeloid leukemia: an overview," Mediterranean Journal of Hematology and Infectious Diseases, vol. 6, no. 1, 2014.

[20] M. Dimou and P. Panayiotidis, "Tyrosine kinase inhibitors and interferon," Mediterranean Journal of Hematology and Infectious Diseases, vol. 6, no. 1, Article ID e2014006, 2014.

[21] S. G. O'Brien, F. Guilhot, R. A. Larson et al., "Imatinib compared with interferon and low-dose cytarabine for newly diagnosed chronic-phase chronic myeloid leukemia," The New England Journal of Medicine, vol. 348, no. 11, pp. 994-1004, 2003.

[22] M. E. Gorre, M. Mohammed, K. Ellwood et al., "Clinical resistance to STI-571 cancer therapy caused by BCR-ABL gene mutation or amplification," Science, vol. 293, no. 5531, pp. 876$880,2001$.

[23] P. le Coutre, E. Tassi, M. Varella-Garcia et al., "Induction of resistance to the Abelson inhibitor STI571 in human leukemic cells through gene amplification," Blood, vol. 95, no. 5, pp. 1758$1766,2000$. 
[24] E. J. Jabbour, J. E. Cortes, and H. M. Kantarjian, "Resistance to tyrosine kinase inhibition therapy for chronic myelogenous leukemia: a clinical perspective and emerging treatment options," Clinical Lymphoma, Myeloma and Leukemia, vol. 13, no. 5, pp. 515-529, 2013.

[25] N. J. Donato, J. Y. Wu, J. Stapley et al., "BCR-ABL independence and LYN kinase overexpression in chronic myelogenous leukemia cells selected for resistance to STI571," Blood, vol. 101, no. 2, pp. 690-698, 2003.

[26] S. Chakraborty, Y.-H. Lin, X. Leng et al., "Activation of Jak2 in patients with blast crisis chronic myelogenous leukemia: inhibition of Jak2 inactivates Lyn kinase," Blood Cancer Journal, vol. 3, p. 142, 2013.

[27] Y. Kuwazuru, A. Yoshimura, S. Hanada et al., "Expression of the multidrug transporter, P-glycoprotein, in chronic myelogenous leukaemia cells in blast crisis," British Journal of Haematology, vol. 74, no. 1, pp. 24-29, 1990.

[28] F.-X. Mahon, F. Belloc, V. Lagarde et al., "MDR1 gene overexpression confers resistance to imatinib mesylate in leukemia cell line models," Blood, vol. 101, no. 6, pp. 2368-2373, 2003.

[29] L. P. Akard, "Second-generation BCR-ABL kinase inhibitors in CML," The New England Journal of Medicine, vol. 363, no. 17, pp. 1672-1673, 2010.

[30] C. T. Chuah, H. Nakamae, Z. X. Shen, M. B. Bradley-Garelik, and D.-W. Kim, "Efficacy and safety of dasatinib versus imatinib in the East Asian subpopulation of the DASISION trial of newly diagnosed chronic myeloid leukemia in chronic phase," Leukemia and Lymphoma, vol. 55, no. 9, pp. 2093-2100, 2014.

[31] H. M. Kantarjian, A. Hochhaus, G. Saglio et al., "Nilotinib versus imatinib for the treatment of patients with newly diagnosed chronic phase, Philadelphia chromosome-positive, chronic myeloid leukaemia: 24-month minimum follow-up of the phase 3 randomised ENESTnd trial," The Lancet Oncology, vol. 12, no. 9, pp. 841-851, 2011.

[32] C. Gambacorti-Passerini, J. E. Cortes, J. H. Lipton et al., "Safety of bosutinib versus imatinib in the phase 3 BELA trial in newly diagnosed chronic phase chronic myeloid leukemia," American Journal of Hematology, vol. 89, no. 10, pp. 947-953, 2014.

[33] R. Ferdinand, S. A. Mitchell, S. Batson, and I. Tumur, "Treatments for chronic myeloid leukemia: a qualitative systematic review," Journal of Blood Medicine, vol. 3, pp. 51-76, 2012.

[34] M. Breccia, A. Salaroli, M. Molica, and G. Alimena, "Systematic review of dasatinib in chronic myeloid leukemia," OncoTargets and Therapy, vol. 6, pp. 257-265, 2013.

[35] M. Steinberg, "Dasatinib: a tyrosine kinase inhibitor for the treatment of chronic myelogenous leukemia and philadelphia chromosome-positive acute lymphoblastic leukemia," Clinical Therapeutics, vol. 29, no. 11, pp. 2289-2308, 2007.

[36] R. Chen and B. Chen, "The role of dasatinib in the management of chronic myeloid leukemia," Drug Design, Development and Therapy, vol. 9, pp. 773-779, 2015.

[37] P. P. Piccaluga, S. Paolini, and G. Martinelli, “Tyrosine kinase inhibitors for the treatment of Philadelphia chromosomepositive adult acute lymphoblastic leukemia," Cancer, vol. 110, no. 6, pp. 1178-1186, 2007.

[38] D. L. DeRemer, C. Ustun, and K. Natarajan, "Nilotinib: a second-generation tyrosine kinase inhibitor for the treatment of chronic myelogenous leukemia," Clinical Therapeutics, vol. 30, no. 11, pp. 1956-1975, 2008.

[39] P. P. Piccaluga, S. Paolini, C. Bertuzzi, A. de Leo, and G. Rosti, "First-line treatment of chronic myeloid leukemia with nilotinib: critical evaluation," Journal of Blood Medicine, vol. 3, pp. 151-156, 2012.

[40] G. Keller-von Amsberg and P. Schafhausen, "Bosutinib in the management of chronic myelogenous leukemia," Biologics: Targets and Therapy, vol. 7, no. 1, pp. 115-122, 2013.

[41] G. K.-V. Amsberg and S. Koschmieder, "Profile of bosutinib and its clinical potential in the treatment of chronic myeloid leukemia," OncoTargets and Therapy, vol. 6, pp. 99-106, 2013.

[42] S. Isfort, G. Keller-v Amsberg, P. Schafhausen, S. Koschmieder, and T. H. Brummendorf, "Bosutinib: a novel second-generation tyrosine kinase inhibitor," in Small Molecules in Oncology, vol. 201 of Recent Results in Cancer Research, pp. 81-97, Springer, Berlin, Germany, 2014.

[43] C. L. Shamroe and J. M. Comeau, "Ponatinib: a new tyrosine kinase inhibitor for the treatment of chronic myeloid leukemia and Philadelphia chromosome-positive acute lymphoblastic leukemia," The Annals of Pharmacotherapy, vol. 47, no. 11, pp. 1540-1546, 2013.

[44] H. G. Drexler, R. A. F. MacLeod, and C. C. Uphoff, "Leukemia cell lines: in vitro models for the study of Philadelphia chromosome-positive leukemia," Leukemia Research, vol. 23, no. 3, pp. 207-215, 1999.

[45] C. B. Lozzio and B. B. Lozzio, "Human chronic myelogenous leukemia cell-line with positive Philadelphia chromosome," Blood, vol. 45, no. 3, pp. 321-334, 1975.

[46] R. A. van Etten, "Models of chronic myeloid leukemia," Current Oncology Reports, vol. 3, no. 3, pp. 228-237, 2001.

[47] F. Ritossa, "Discovery of the heat shock response," Cell Stress Chaperones, vol. 1, no. 2, pp. 97-98, 1996.

[48] J. Frydman, "Folding of newly translated proteins in vivo: the role of molecular chaperones," Annual Review of Biochemistry, vol. 70, pp. 603-647, 2001.

[49] H. H. Kampinga, "Chaperones in preventing protein denaturation in living cells and protecting against cellular stress," in Molecular Chaperones in Health and Disease, vol. 172 of Handbook of Experimental Pharmacology, pp. 1-42, Springer, Berlin, Germany, 2006.

[50] C. Sõti, E. Nagy, Z. Giricz, L. Vígh, P. Csermely, and P. Ferdinandy, "Heat shock proteins as emerging therapeutic targets," British Journal of Pharmacology, vol. 146, no. 6, pp. 769-780, 2005.

[51] C. Jolly and R. I. Morimoto, "Role of the heat shock response and molecular chaperones in oncogenesis and cell death," Journal of the National Cancer Institute, vol. 92, no. 19, pp. 1564-1572, 2000.

[52] R. I. Morimoto, M. P. Kline, D. N. Bimston, and J. J. Cotto, "The heat-shock response: regulation and function of heat-shock proteins and molecular chaperones," Essays in Biochemistry, vol. 32, pp. 17-29, 1997.

[53] M. V. Powers and P. Workman, "Inhibitors of the heat shock response: biology and pharmacology," FEBS Letters, vol. 581, no. 19, pp. 3758-3769, 2007.

[54] Y. Hu and N. F. Mivechi, "HSF-1 interacts with Ral-binding protein 1 in a stress-responsive, multiprotein complex with HSP90 in vivo," The Journal of Biological Chemistry, vol. 278, no. 19, pp. 17299-17306, 2003.

[55] A. A. Khalil, N. F. Kabapy, S. F. Deraz, and C. Smith, "Heat shock proteins in oncology: diagnostic biomarkers or therapeutic targets?" Biochimica et Biophysica Acta, vol. 1816, no. 2, pp. 89104, 2011. 
[56] M. Yonehara, Y. Minami, Y. Kawata, J. Nagai, and I. Yahara, "Heat-induced chaperone activity of HSP90," The Journal of Biological Chemistry, vol. 271, no. 5, pp. 2641-2645, 1996.

[57] T. Nemoto, N. Sato, H. Iwanari, H. Yamashita, and T. Takagi, "Domain structures and immunogenic regions of the $90-\mathrm{kDa}$ heat-shock protein (HSP90). Probing with a library of antiHSP90 monoclonal antibodies and limited proteolysis," The Journal of Biological Chemistry, vol. 272, no. 42, pp. 26179-26187, 1997.

[58] P. Csermely, T. Schnaider, C. Soti, Z. Prohászka, and G. Nardai, "The 90-kDa molecular chaperone family: structure, function, and clinical applications. A comprehensive review," Pharmacology and Therapeutics, vol. 79, no. 2, pp. 129-168, 1998.

[59] L. H. Pearl and C. Prodromou, "Structure and mechanism of the Hsp90 molecular chaperone machinery," Annual Review of Biochemistry, vol. 75, pp. 271-294, 2006.

[60] C. Prodromou and L. H. Pearl, "Structure and functional relationships of Hsp90," Current Cancer Drug Targets, vol. 3, no. 5, pp. 301-323, 2003.

[61] J. Fontana, D. Fulton, Y. Chen et al., "Domain mapping studies reveal that the $\mathrm{M}$ domain of hsp90 serves as a molecular scaffold to regulate Akt-dependent phosphorylation of endothelial nitric oxide synthase and NO release," Circulation Research, vol. 90, no. 8, pp. 866-873, 2002.

[62] A. Carrello, E. Ingley, R. F. Minchin, S. Tsai, and T. Ratajczak, "The common tetratricopeptide repeat acceptor site for steroid receptor-associated immunophilins and Hop is located in the dimerization domain of Hsp90," The Journal of Biological Chemistry, vol. 274, no. 5, pp. 2682-2689, 1999.

[63] L. H. Pearl, C. Prodromou, and P. Workman, "The Hsp90 molecular chaperone: an open and shut case for treatment," The Biochemical Journal, vol. 410, no. 3, pp. 439-453, 2008.

[64] D. Hanahan and R. A. Weinberg, "The hallmarks of cancer," Cell, vol. 100, no. 1, pp. 57-70, 2000.

[65] H. Zhang and F. Burrows, "Targeting multiple signal transduction pathways through inhibition of Hsp90," Journal of Molecular Medicine, vol. 82, no. 8, pp. 488-499, 2004.

[66] M. Taipale, D. F. Jarosz, and S. Lindquist, "HSP90 at the hub of protein homeostasis: emerging mechanistic insights," Nature Reviews Molecular Cell Biology, vol. 11, no. 7, pp. 515-528, 2010.

[67] K. Richter, P. Muschler, O. Hainzl, and J. Buchner, "Coordinated ATP hydrolysis by the Hsp90 Dimer," The Journal of Biological Chemistry, vol. 276, no. 36, pp. 33689-33696, 2001.

[68] A. J. McClellan, Y. Xia, A. M. Deutschbauer, R. W. Davis, M. Gerstein, and J. Frydman, "Diverse cellular functions of the Hsp90 molecular chaperone uncovered using systems approaches," Cell, vol. 131, no. 1, pp. 121-135, 2007.

[69] G. Jego, A. Hazoumé, R. Seigneuric, and C. Garrido, “Targeting heat shock proteins in cancer," Cancer Letters, vol. 332, no. 2, pp. 275-285, 2013.

[70] L. Neckers, "Hsp90 inhibitors as novel cancer chemotherapeutic agents," Trends in Molecular Medicine, vol. 8, no. 4, pp. S55-S61, 2002.

[71] M. Žáčková, D. Moučková, T. Lopotová, Z. Ondráčková, H. Klamová, and J. Moravcová, "Hsp90-a potential prognostic marker in CML," Blood Cells, Molecules, and Diseases, vol. 50, no. 3, pp. 184-189, 2013.

[72] C. DeBoer, P. A. Meulman, R. J. Wnuk, and D. H. Peterson, "Geldanamycin, a new antibiotic," The Journal of Antibiotics, vol. 23, no. 9, pp. 442-447, 1970.
[73] T. W. Schulte and L. M. Neckers, "The benzoquinone ansamycin 17-allylamino-17-demethoxygeldanamycin binds to HSP90 and shares important biologic activities with geldanamycin," Cancer Chemotherapy and Pharmacology, vol. 42, no. 4, pp. 273-279, 1998.

[74] R. Nimmanapalli, E. O’Bryan, and K. Bhalla, "Geldanamycin and its analogue 17-allylamino-17-demethoxygeldanamycin lowers Bcr-Abl levels and induces apoptosis and differentiation of Bcr-Abl-positive human leukemic blasts," Cancer Research, vol. 61, no. 5, pp. 1799-1804, 2001.

[75] M. J. Egorin, T. F. Lagattuta, D. R. Hamburger et al., "Pharmacokinetics, tissue distribution, and metabolism of 17-(dimethylaminoethylamino)-17-demethoxygeldanamycin (NSC 707545) in CD $2 \mathrm{f} 1$ mice and fischer 344 rats," Cancer Chemotherapy and Pharmacology, vol. 49, no. 1, pp. 7-19, 2002.

[76] T. K. Nguyen, M. Rahmani, N. Gao et al., "Synergistic interactions between DMAG and mitogen-activated protein kinase kinase $1 / 2$ inhibitors in $\mathrm{Bcr} / \mathrm{abl}^{+}$leukemia cells sensitive and resistant to imatinib mesylate," Clinical Cancer Research, vol. 12, no. 7, pp. 2239-2247, 2006.

[77] P. George, P. Bali, S. Annavarapu et al., "Combination of the histone deacetylase inhibitor LBH589 and the hsp90 inhibitor 17-AAG is highly active against human CML-BC cells and AML cells with activating mutation of FLT-3," Blood, vol. 105, no. 4, pp. 1768-1776, 2005.

[78] M. Rahmani, C. Yu, Y. Dai et al., "Coadministration of the heat shock protein 90 antagonist 17-allylamino-17-demethoxygeldanamycin with suberoylanilide hydroxamic acid or sodium butyrate synergistically induces apoptosis in human leukemia cells," Cancer Research, vol. 63, no. 23, pp. 8420-8427, 2003.

[79] W. Ying, Z. Du, L. Sun et al., "Ganetespib, a unique triazolonecontaining Hsp90 inhibitor, exhibits potent antitumor activity and a superior safety profile for cancer therapy," Molecular Cancer Therapeutics, vol. 11, no. 2, pp. 475-484, 2012.

[80] T. Shimamura, S. A. Perera, K. P. Foley et al., "Ganetespib (STA9090), a nongeldanamycin HSP90 inhibitor, has potent antitumor activity in in vitro and in vivo models of non-small cell lung cancer," Clinical Cancer Research, vol. 18, no. 18, pp. 4973-4985, 2012.

[81] M. Lazenby, R. Hills, A. Burnett, and J. Zabkiewicz, "The HSP90 inhibitor ganetespib: a potential effective agent for Acute Myeloid Leukemia in combination with cytarabine," Leukemia Research, vol. 39, no. 6, pp. 617-624, 2015.

[82] Y. Uehara, "Natural product origins of Hsp90 inhibitors," Current Cancer Drug Targets, vol. 3, no. 5, pp. 325-330, 2003.

[83] S. Canova, V. Bellosta, A. Bigot, P. Mailliet, S. Mignani, and J. Cossy, "Total synthesis of herbimycin A," Organic Letters, vol. 9, no. 1, pp. 145-148, 2007.

[84] H. Ren, S. Chen, and D. Lu, "Effect of combination of herbimycin A, an inhibitor of tyrosine kinase, and chemotherapeutic agents on apoptosis of K562 cells," Zhonghua Xue Ye Xue Za Zhi, vol. 18 , no. 5, pp. 227-230, 1997.

[85] C. J. Martin, S. Gaisser, I. R. Challis et al., "Molecular characterization of macbecin as an Hsp90 inhibitor," Journal of Medicinal Chemistry, vol. 51, no. 9, pp. 2853-2857, 2008.

[86] Y. Ono, Y. Kozai, and K. Ootsu, "Antitumor and cytocidal activities of a newly isolated benzenoid ansamycin, macbecinI," Gan, vol. 73, no. 6, pp. 938-944, 1982.

[87] T. W. Schulte, S. Akinaga, S. Soga et al., "Antibiotic radicicol binds to the N-terminal domain of Hsp90 and shares important 
biologic activities with geldanamycin," Cell Stress and Chaperones, vol. 3, no. 2, pp. 100-108, 1998.

[88] S. Soga, Y. Shiotsu, S. Akinaga, and S. V. Sharma, "Development of radicicol analogues," Current Cancer Drug Targets, vol. 3, no. 5, pp. 359-369, 2003.

[89] S. Soga, L. M. Neckers, T. W. Schulte et al., "KF25706, a novel oxime derivative of radicicol, exhibits in vivo antitumor activity via selective depletion of Hsp90 binding signaling molecules," Cancer Research, vol. 59, no. 12, pp. 2931-2938, 1999.

[90] F. Morceau, I. Buck, M. Dicato, and M. Diederich, "Radicicolmediated inhibition of Bcr-Abl in K562 cells induced p38MAPK dependent erythroid differentiation and PU.1 downregulation," BioFactors, vol. 34, no. 4, pp. 313-329, 2008.

[91] M. G. Marcu, A. Chadli, I. Bouhouche, M. Catelli, and L. M. Neckers, "The heat shock protein 90 antagonist novobiocin interacts with a previously unrecognized ATP-binding domain in the carboxyl terminus of the chaperone," The Journal of Biological Chemistry, vol. 275, no. 47, pp. 37181-37186, 2000.

[92] L. X. Wu, J. H. Xu, K. Z. Zhang et al., "Disruption of the Bcr-Abl/Hsp90 protein complex: a possible mechanism to inhibit Bcr-Abl-positive human leukemic blasts by novobiocin," Leukemia, vol. 22, no. 7, pp. 1402-1409, 2008.

[93] C. M. Palermo, J. I. Martin Hernando, S. D. Dertinger, A. S. Kende, and T. A. Gasiewicz, "Identification of potential aryl hydrocarbon receptor antagonists in green tea," Chemical Research in Toxicology, vol. 16, no. 7, pp. 865-872, 2003.

[94] C. M. Palermo, C. A. Westlake, and T. A. Gasiewicz, "Epigallocatechin gallate inhibits aryl hydrocarbon receptor gene transcription through an indirect mechanism involving binding to a $90 \mathrm{kDa}$ heat shock protein," Biochemistry, vol. 44, no. 13, pp. 5041-5052, 2005.

[95] J. H. Jung, M. Yun, E. Choo et al., "A derivative of epigallocatechin-3-gallate induces apoptosis via SHP-1-mediated suppression of BCR-ABL and STAT3 signalling in chronic myelogenous leukaemia," British Journal of Pharmacology, vol. 172, no. 14, pp. 3565-3578, 2015.

[96] B. Goker, C. Caliskan, H. O. Caglar et al., "Synergistic effect of ponatinib and epigallocatechin-3-gallate induces apoptosis in chronic myeloid leukemia cells through altering expressions of cell cycle regulatory genes," Journal of B.U.ON., vol. 19, no. 4, pp. 992-998, 2014.

[97] M. C. Wani, H. L. Taylor, M. E. Wall, P. Coggon, and A. T. McPhail, "Plant antitumor agents. VI. The isolation and structure of taxol, a novel antileukemic and antitumor agent from Taxus brevifolia," Journal of the American Chemical Society, vol. 93, no. 9, pp. 2325-2327, 1971.

[98] P. B. Schiff and S. B. Horwitz, "Taxol stabilizes microtubules in mouse fibroblast cells," Proceedings of the National Academy of Sciences of the United States of America, vol. 77, no. 3, pp. 1561$1565,1980$.

[99] D. B. Solit, A. D. Basso, A. B. Olshen, H. I. Scher, and N. Rosen, "Inhibition of heat shock protein 90 function down-regulates Akt kinase and sensitizes tumors to Taxol," Cancer Research, vol. 63, no. 9, pp. 2139-2144, 2003.

[100] A. Sawai, S. Chandarlapaty, H. Greulich et al., "Inhibition of Hsp90 down-regulates mutant epidermal growth factor receptor (EGFR) expression and sensitizes EGFR mutant tumors to paclitaxel," Cancer Research, vol. 68, no. 2, pp. 589-596, 2008.

[101] O. Bucur, A. L. Stancu, I. Goganau et al., "Combination of bortezomib and mitotic inhibitors down-modulate Bcr-Abl and efficiently eliminates tyrosine-kinase inhibitor sensitive and resistant Bcr-Abl-positive leukemic cells," PLoS ONE, vol. 8, no. 10, Article ID e77390, 2013.

[102] J. Davenport, J. R. Manjarrez, L. Peterson, B. Krumm, B. S. J. Blagg, and R. L. Matts, "Gambogic acid, a natural product inhibitor of Hsp90," Journal of Natural Products, vol. 74, no. 5, pp. 1085-1092, 2011.

[103] L. Zhang, Y. Yi, J. Chen et al., "Gambogic acid inhibits Hsp90 and deregulates TNF- $\alpha / \mathrm{NF}-\kappa \mathrm{B}$ in HeLa cells," Biochemical and Biophysical Research Communications, vol. 403, no. 3-4, pp. 282-287, 2010.

[104] X. Shi, X. Chen, X. Li et al., "Gambogic acid induces apoptosis in imatinib-resistant chronic myeloid leukemia cells via inducing proteasome inhibition and caspase-dependent Bcr-Abl downregulation," Clinical Cancer Research, vol. 20, no. 1, pp. 151-163, 2014.

[105] A. Salminen, M. Lehtonen, T. Paimela, and K. Kaarniranta, "Celastrol: molecular targets of Thunder God Vine," Biochemical and Biophysical Research Communications, vol. 394, no. 3, pp. 439-442, 2010.

[106] T. Zhang, A. Hamza, X. Cao et al., "A novel Hsp90 inhibitor to disrupt Hsp90/Cdc37 complex against pancreatic cancer cells," Molecular Cancer Therapeutics, vol. 7, no. 1, pp. 162-170, 2008.

[107] H. Hieronymus, J. Lamb, K. N. Ross et al., "Gene expression signature-based chemical genomic prediction identifies a novel class of HSP90 pathway modulators," Cancer Cell, vol. 10, no. 4, pp. 321-330, 2006.

[108] Z. Lu, Y. Jin, L. Qiu, Y. Lai, and J. Pan, "Celastrol, a novel HSP90 inhibitor, depletes Bcr-Abl and induces apoptosis in imatinibresistant chronic myelogenous leukemia cells harboring T315I mutation," Cancer Letters, vol. 290, no. 2, pp. 182-191, 2010.

[109] Y. Guo, Y. Li, Q. Shan, G. He, J. Lin, and Y. Gong, "Curcumin potentiates the anti-leukemia effects of imatinib by downregulation of the AKT/mTOR pathway and $B C R / A B L$ gene expression in $\mathrm{Ph}^{+}$acute lymphoblastic leukemia," The International Journal of Biochemistry \& Cell Biology, vol. 65, pp. 1-11, 2015.

[110] C. Giommarelli, V. Zuco, E. Favini et al., "The enhancement of antiproliferative and proapoptotic activity of HDAC inhibitors by curcumin is mediated by Hsp90 inhibition," Cellular and Molecular Life Sciences, vol. 67, no. 6, pp. 995-1004, 2010.

[111] L.-X. Wu, Y. Wu, R.-J. Chen et al., "Curcumin derivative C817 inhibits proliferation of imatinib-resistant chronic myeloid leukemia cells with wild-type or mutant Bcr-Abl in vitro," Acta Pharmacologica Sinica, vol. 35, no. 3, pp. 401-409, 2014.

[112] M. Rai, P. S. Jogee, G. Agarkar, and C. A. Santos, "Anticancer activities of Withania somnifera: current research, formulations, and future perspectives," Pharmaceutical Biology, pp. 1-9, 2015.

[113] M. Narayan, J. Zhang, K. Braswell et al., "Withaferin A regulates LRRK2 levels by interfering with the Hsp90-Cdc37 chaperone complex," Current Aging Science, vol. 8, no. 3, pp. 259-265, 2015.

[114] M. K. McKenna, B. W. Gachuki, S. S. Alhakeem et al., "Anticancer activity of withaferin A in B-cell lymphoma," Cancer Biology \& Therapy, vol. 16, no. 7, pp. 1088-1098, 2015.

[115] W. Suttana, S. Mankhetkorn, W. Poompimon et al., "Differential chemosensitization of P-glycoprotein overexpressing K562/Adr cells by withaferin A and Siamois polyphenols," Molecular Cancer, vol. 9, article 99, 2010.

[116] K.-J. Huang, Y.-C. Chen, M. El-Shazly et al., "5-Episinuleptolide acetate, a norcembranoidal diterpene from the formosan soft coral Sinularia sp., induces leukemia cell apoptosis through Hsp90 inhibition," Molecules, vol. 18, no. 3, pp. 2924-2933, 2013. 
[117] W. Aherne, A. Maloney, C. Prodromou et al., "Assays for Hsp90 and inhibitors," in Novel Anti Cancer Drug Protocols, vol. 85 of Methods In Molecular Medicine, pp. 149-161, Springer, Berlin, Germany, 2003.

[118] A. A. Baykov, O. A. Evtushenko, and S. M. Avaeva, "A malachite green procedure for orthophosphate determination and its use in alkaline phosphatase based enzyme immunoassay," Analytical Biochemistry, vol. 171, no. 2, pp. 266-270, 1988.

[119] P. A. Lanzetta, L. J. Alvarez, P. S. Reinach, and O. A. Candia, "An improved assay for nanomole amounts of inorganic phosphate," Analytical Biochemistry, vol. 100, no. 1, pp. 95-97, 1979.

[120] S. J. Gould and S. Subramani, "Firefly luciferase as a tool in molecular and cell biology," Analytical Biochemistry, vol. 175, no. 1, pp. 5-13, 1988.

[121] J. Davenport, M. Balch, L. Galam et al., "High-throughput screen of natural product libraries for Hsp90 inhibitors," Biology, vol. 3, no. 1, pp. 101-138, 2014.

[122] https://clinicaltrials.gov/ct2/results?term=NCT00100997\&cond= $\% 22$ Chronic+Myeloid+Leukemia $\% 22$.

[123] https://clinicaltrials.gov/ct2/show/NCT00964873?term $=$ NCT00964873\&rank=1.

[124] https://clinicaltrials.gov/ct2/show/NCT00003230?term= NCT00003230\&rank=1. 


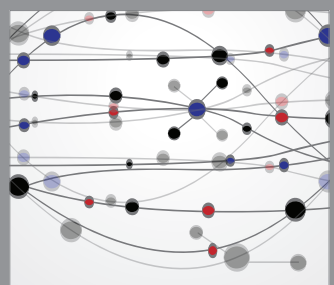

The Scientific World Journal
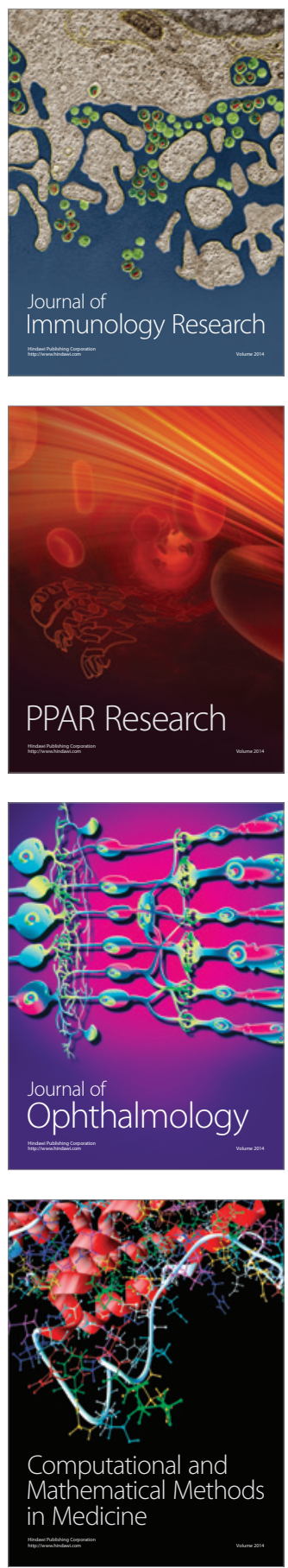

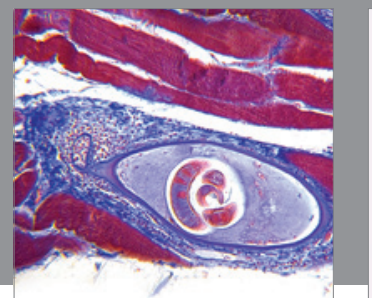

Gastroenterology

Research and Practice
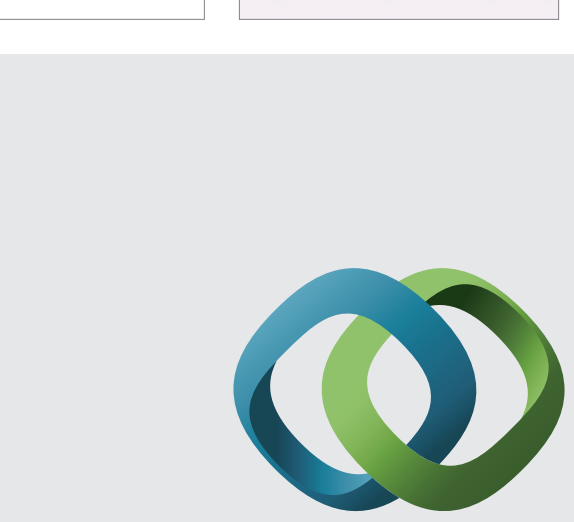

\section{Hindawi}

Submit your manuscripts at

http://www.hindawi.com
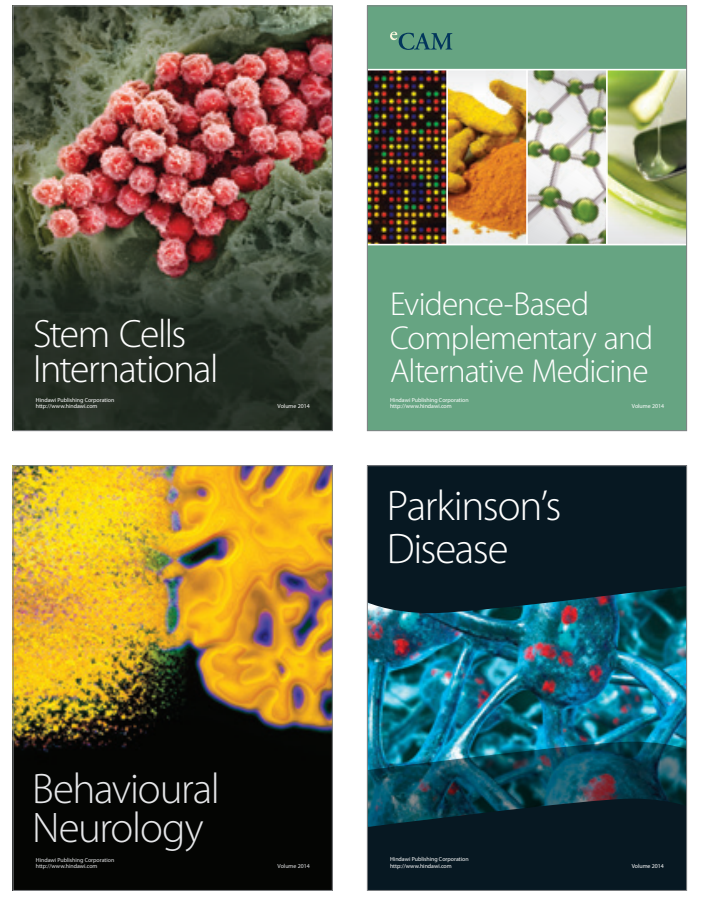
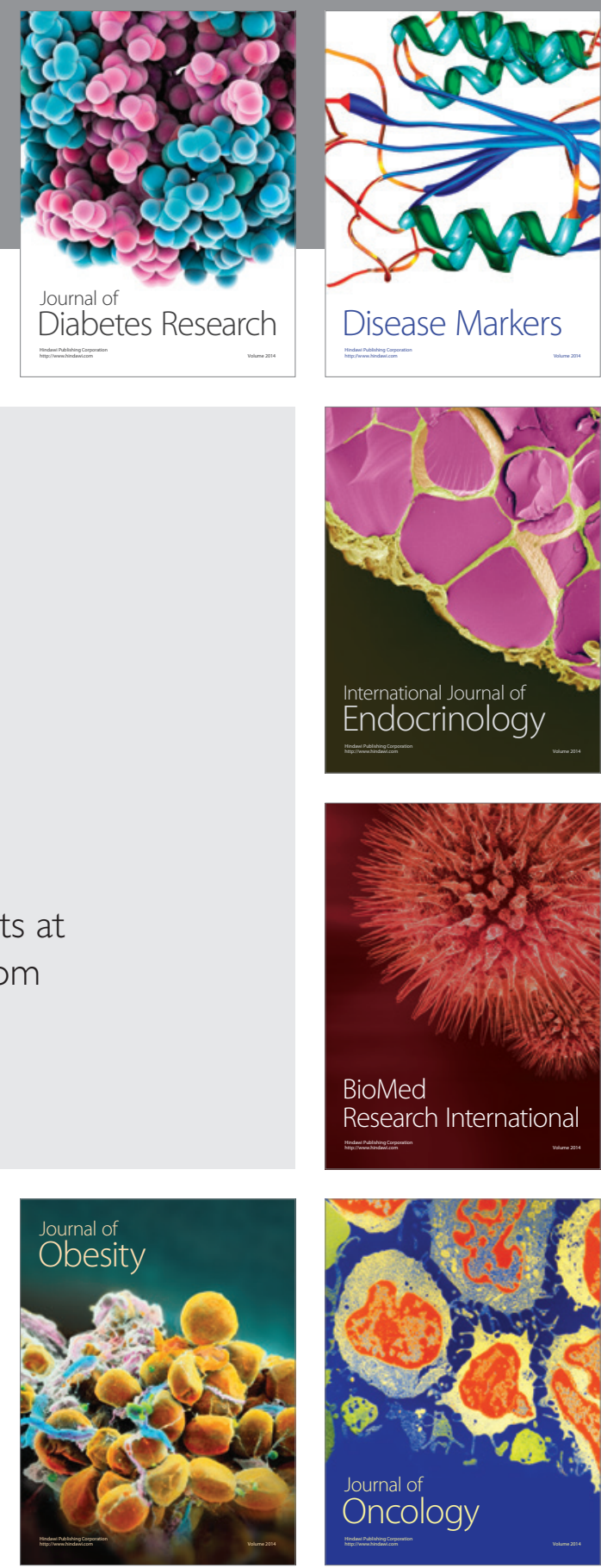

Disease Markers
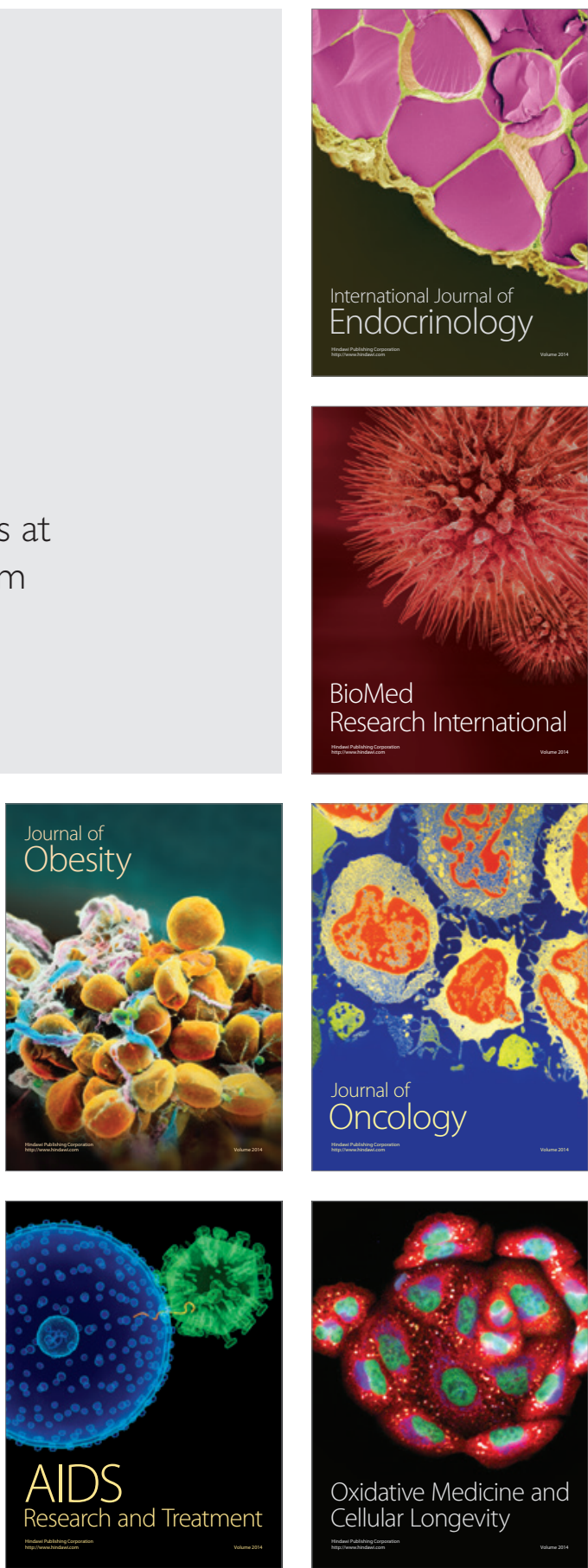